\title{
Faxian and Liu Yu's Inner Circle: Interactions between Society and Buddhism during the Eastern Jin Dynasty*
}

\author{
LIU YUAN-JU 劉苑如 \\ Academia Sinica \\ ju@gate.sinica.edu.tw
}

Keywords: Faxian, Liu Yu and his circle, Longhua monastery, Daochang Monastery, Xing Monastery

DOI: https://dx.doi.org/10.15239/hijbs.02.01.07

Abstract: This article discusses the interaction between Faxian (338?-423?) and Liu Yu (363-422) and his circles, especially the relations within the sangha in Qingxu and Jingzhou, from the point of geo-relationship and of dharma-associated practices, to remodel the social networks and Buddhist background of the Eastern Jin and the Sixteen Kingdoms, to discuss the protection of Buddhism by Liu Yu's circles, and to highlight the contribution of Faxian to it. There are some important hints as to that. First, Faxian came back to Qingzhou, which coincided with the time when Liu Yu had reclaimed the provinces of Qing, Yan and Si, and planned to establish the kingdom of Song. As soon as Faxian reached land, he was invited by Liu Yu's younger brother, Liu Yan (Dao Lian, 368-422) to build a monastery called Longhua in Pengcheng. Second, he translated sutras and vinaya texts together with Buddhabhadra (359-429) at Daochang

This essay is a product of the digital humanities 'East Asia Literature and Culture Map' of the Institute of Chinese Literature and Philosophy, Academia 
Monastery in Jiankang, during the twelfth and fourteenth year of the Yixi period, with the support of the benefactors from Liu Yu's clique Meng Yi and Chu Shudu (378-424). Lastly, he went to Xing Monastery in Jingzhou for his last days, this was also a consequence of Liu Yu's power. During his lifetime rich in travel, with the spread of Buddhism to the east, Faxian was connected to several important places of the Buddhist sangha, which is also closely related to the choice and acceptance of the Buddhist doctrine in China, and which constructed a complicated circle of Buddhist believers.

\section{Introduction: The Meeting between Faxian and Liu Yu's Inner Circle}

$\mathrm{I}$

n 399 CE, Master Faxian (338?-423?) was inspired to leave Chang'an and head toward the Indian subcontinent in search of scriptures by the fact that only an incomplete version of the Vinayapitaka was available 律藏殘閣 in China. During the time he was gone, the Later Qin progressively grew in strength, acquiring more and more territories that had previously been occupied by the Eastern Jin. However, when Faxian returned to Qingzhou after thirteen years of travel, the geopolitical trajectory of China had completely reversed. Helian Bobo 赫連勃勃 (381-425) of the state of Daxia 大 夏 had repeatedly led his troops south to harass the Later Qin, resulting in the loss of nearly a 100,000 troops, the looting of no less than 20,000 homes, the destruction of countless livestock and assets, and ultimately the decline of the Later Qin. Meanwhile, Liu Yu 劉裕

Sinica. It also extensively used resources from the Dharma Drum Institute of Liberal Art's 法鼓山佛教學院 'Visualizing and Querying Chinese Buddhist Biographies’ 佛教傳記文學 platform. It was first published at the international research forum 'From Xiangyuan to Ceylon, the Life and Legacy of Han Buddhist Monk Faxian (337-422)' 從襄垣到錫蘭: 漢僧法顯 (337-422) 其生平與遺產, which was held in Xiangyuan County, Shanxi Province, China (PRC), in 2017. The author feels indebted to the professors Feng Guodong 馮國棟 and Wang Xuemei 王雪梅 for their criticism and corrections, and is also deeply thankful for the suggestions of Wang Fuzhen 王福楨. 
(363-422) had been busy turning the tide for the previously faltering Eastern Jin. Liu Yu annihilated the Southern Yan 南燕 in 410 and the Later Qin shortly after in 417, and then he recaptured the northern lands of Qingzhou, Yanzhou, and Sizhou. Following these achievements came a series of events initiated by Liu Yu that ended with the formation of the Liu Song 劉宋 (420-479) Dynasty—a dynasty of which he was declared emperor.

Faxian returned from Sinhala 師子國 (Ceylon, modern day Sri Lanka) by sea in $412 \mathrm{CE}$. He arrived at the shores of Qingzhou, a land that was under the influence of Liu's inner circle 劉氏. There, Liu Yan 劉㳘 (a.k.a. Liu Daolian 道憐, 368-422), a brother of Liu $\mathrm{Yu}$, invited Faxian to stay in Jingkou 京口 from the winter of 412 to the summer of $413,{ }^{1}$ during which Faxian established the Longhua Monastery 龍華寺. ${ }^{2}$ Later, in either 413 or 414 , Huiyuan 慧 遠 (334-416?/417?) invited Faxian to Lushan. ${ }^{3}$ This was likely

1 The Faxian zhuan jiaozhu 法顯傳校注 [Faxian zbuan, Collated and Annotated] by Zhang Xun 章巽 and its corresponding annotations reads: '[he] invited Faxian to stay from the winter to the summer'. Adachi Kiroku 足立喜六 believes Faxian came to Yangzhou by ship with merchants, and was then invited by Liu Daoling to spend a winter through a summer in Jingkou. Tang Yongtong 湯用坓, however, does not agree with this notion and instead believes that after Faxian arrived on shore at Laoshan, he travelled to the south by land, passing through Pengcheng along the way. At that time, Liu Daolian was the governor of North Xuzhou and Yanzhou, and he was based in Pengcheng. Tang Yongtong suspects that Liyi 李 嶷, a military officer under Liu Daolian's command, suggested to Liu Daolian that he should retain Faxian and support him. This article supports the latter opinion. See Zhang, annot., Faxian zhuan jiaozbu, 175.

2 Rao, 'Zaoqi Qingzhou Cheng yu Fojiao', 52.

3 There has always been disagreement over whether or not Faxian actually went to Lushan. The arguments suggesting he did go to Lushan are epitomized in Zhang Xun's The Collated and Annotated Record of Faxian and Kimura Eiichi's 'Research on Huiyuan: Lost Text'. See Zhang, annot., Faxian zhuan jiaozhu, 180; Kimura, Eon Kenkyū, 46 (see footnote 37 on the 'Buddha Shadow Inscription’ 佛影銘). Some have argued that Faxian did not go to Lushan, such as Chen Jinhua 陳金華. See Chen, 'Faxian Deng Lufeng'. 
the place where Faxian completed the first draft of Foguo ji 佛國記 [Record of the Buddha Land], a work which describes the dignified and blossoming Buddhist nation he experienced to the west of China, along with the geography and local customs of that land. ${ }^{4}$ Next, around 416 to 418, Meng Yi 孟顗 (384-465) and Chu Shudu 褚叔度 (378-424) of Liu Yi's inner circle supported Faxian's collaborative translation work with Buddhabhadra 佛跎跋陀羅 (359-429) at Daochang Monastery 道場寺, which resulted in Chinese editions of many Buddhist scriptures and Vinaya 律. Finally, at some point after 418, Faxian went to Jingzhou, which Liu Yu had already established control over, and later spent his final years at Xin Monastery 辛寺.

Faxian lived a life of abundant travel. He was involved with several monasteries vital to Buddhism's transmission to the East and central to the selection of Buddhist doctrines that became accepted throughout Han Chinese lands. Accordingly, a complicated web of Buddhist groups materialized under his watch. I previously performed a separate study of the interaction between Faxian and the inner circle of Huiyuan of Lushan, ${ }^{5}$ and I have also studied the relationship between Faxian and the project of translating Buddhist texts that was carried out at Daochang Monastery. ${ }^{6}$ However, I have done relatively little research on the society and culture that served as a backdrop to Faxian's translations of scriptures following his return to China. This paper compares a variety of different, important perspectives from geopolitical and Buddhist lenses. It intends to unearth just how Faxian interacted with Liu Yu's inner circle-especially with respect to how this related to the Buddhist groups in Qingzhou, Xuzhou, and Jingzhou-and reveal exactly what kind of influence Faxian had on Buddhism and politics during his life.

$4 \quad$ Liu, 'Gushi de zaisheng'.

5 Liu, 'Sheyan yu guifan'.

6 Liu, 'Gushi de zaisheng'. 


\section{Military Expeditions, Deferential Treatment, and Worshipping the Buddha}

The formation of Liu Yu's inner circle can be traced back to when he formed a volunteer army. At that time, Liu Yu called together $\mathrm{He}$ Wuji 何無忌 (351-410), Wei Yongzhi 魏詠之 (approx. 375-405), and the brothers Wei Xinzhi 魏欣之 and Wei Shunzhi 魏順之. He also called on Tan Pingzhi 檀憑之 (?-404), who brought relatives with him such as Tan Shao 檀韶 (366-421), Tan Zhi 檀祇 (369419), Tan Long 檀隆, Tan Daoji 檀道濟 (337-436), and Tan Fanzhi 檀範之. There were also Liu Yu's younger brother Liu Daolian 劉道 憐 and his cousins Liu Yi 劉毅 (?-412) and Liu Fan 劉藩 (?-412). In addition, there were Meng Chang 孟昶 (?-410) and Meng Huaiyu 孟懷玉 (385-415), brothers of the same clan. There were also Xiang Mi 向彌 (363-421) of Henei 河內; Guan Yizhi 管義之; and Zhou Anmu 周安穆 of Chenliu 陳留; Liu Wei 劉蔚 of Linhuai 臨淮 and his little brother (從弟) Liu Guizhi 劉珪之; Zang Xi 臓喜 (375-413) of Dongguan 東莞, his cousin Baofu 寶符; and his nephew Musheng 穆生; Tong Maozong 童茂宗; Zhou Daomin 周道民 of Chunjun 陳 郡; Tian Yan 田演 of Yuyang 漁陽; Fan Qing 范清 of Qiaoguo 譙 國; and more. In total, there were twenty-seven central figures to the army, ${ }^{7}$ and they were collectively able to defeat Huan Xuan 桓 玄 (369-404), who had managed to usurp the throne. Afterwards, they carried on under the banner of the Eastern Jin, garnering great renown and progressively expanding their inner circle's sphere of influence. Afterwards, they took advantage of internal strife within the Southern Yan kingdom to crush its troops. Soon after came the task of pacifying Lu Xun's 盧循 (?-411) rebellion, and then they annihilated all other dissidents within the court, such as Liu Yi 劉 毅, Zhuge Zhangmin 諸葛長民 (?-413), and Sima Xiuzhi 司馬休 之 (?-417). Finally, the Eastern Jin carried out expeditions in the north against the Later Qin, wherein they recaptured Luoyang 洛陽 and Guanzhong 關中, thereby obtaining the status of Nine Bestowments 九錫 and establishing the Liu Song Dynasty.

7 Song shu 5.5. 
In virtually all of Liu Yu's campaigns, he was outnumbered but managed to emerge victorious in a seemingly invincible fashion. Relevant research by scholars have identified such factors as the Beifu System 北府制度, superior strategy, and personnel management to account for his success, but in recent years a good deal of scholars have begun paying attention to the beliefs of Liu Yu's family. For example, based on researched cultural images of Liu $\mathrm{Yu}$, Wang Yongping 王永平 posited that Liu used Buddhism to assist his military and political affairs. There were two main ways in which Liu Yu and his inner circle did this: first was the deferential treatment given to leaders of the Sangha from the North and South, such as Huiyuan, Huiguan 慧觀 (366-436?/453?), and Sengdao 僧 導 (362-457), which led to political stability throughout the region; second was the manufacturing of numerous talismans (furui 符瑞), which influenced public opinion about the Song dynasty which Liu Yu founded..$^{8}$ Lin Feifei 林飛飛 expanded the scope of this research, pointing out in her doctoral dissertation, Liusong Diwang $y u$ Zongjiao Guanxi 劉宋帝王與宗教關係 (The Relationship Between Liu Song and Religion), that subsequent emperors of the Liu Song Dynasty essentially continued to use the religious policies of Liu $\mathrm{Yu}$, which at once supported and exploited Buddhism. Specifically, these policies included inviting to the court, and providing deferential treatment to, famous Buddhist monks and nuns; establishing monasteries and making statues; setting up Dharma assemblies; summoning monks to teach the Buddha scriptures; ordering children of the royal family to become friends or disciples of monks and nuns; and even forming friendly ties with other kingdoms that believed in Buddhism. At the same time, Liu Song emperors often called upon preeminent monks to provide them with lectures over Buddhist scripture in which they had interest. They even personally attended Dharma banquets and ordered other high officials to accompany them. This reflects that the emperors valued the growth of Buddhist doctrine and understood the process of how Buddhist doctrine developed. On the other hand, Liu Song emperors also

8 Wang, 'Liu Yu yu Fojiao gaoseng'. 
made sure to carefully control the number of pagodas, temples, and Buddhist statues; remove unqualified monks and nuns; and task officials with managing the Sangha. This was done to prevent Buddhism from infringing on the dynasty's political sovereignty. ${ }^{9}$

While this paper does draw on the research of other papers that discuss the religious and political strategies of the Liu Song Dynasty, it also aims to forge ahead on an entirely new path of study. Specifically, it studies the military expeditions, deferential treatment of certain Buddhists, and the interactions between various social circles in the hopes of opening a new path for research.

Liu Yu spent his whole life waging military campaigns. At some point after his major victories at Luoyang and the Guanzhong during his northern expeditions, he personally recounted his successes while at an official feast of ministers at Ximatai 戲馬臺:

The year Huan Xuan usurped the throne, taking charge of the Eastern Jin's great power, was the first time I advocated for this righteous cause to rejuvenate the royal household.

By campaigning in the South and fighting in the North, I pacified all beneath the sky. It could be called a great accomplishment or an outstanding achievement. And as a result, I was granted the honour of the Nine Bestowments. ${ }^{10}$

Despite such proud words, Liu Yu was ultimately a high-ranking military leader that had led troops into battle. Though he could previously show disdain for the civil and military officials at court, after he took the throne it no longer mattered how many victories he had amassed-he needed to sagaciously appease the commanders, soldiers, officials, and people that had risked their lives following him to the doorstep of death. Accordingly, after Liu Yu founded the Liu Song Dynasty, he issued this imperial order in the first year of his reign:

9 Lin, Liusong diwang.

10 Song shu 43.1336. 
Recording meritorious deeds performed by outstanding men is an important decree of the state; diligently handling the funeral arrangements of those who passed away on behalf of the state is an extension of the sincere wish in my heart. Since this great cause began, seventeen years have passed. There have been challenges in the world and wars have commenced. From the East to the West, there hasn't been a day of peace. In truth, it was the exhausted minds and bodies of generals that brought peace to our land, and the military and civil officials that risked their lives to carry out orders that expanded our territory; the achievements we celebrate today can be traced back to them. Our prestige spreads far and wide; enemy invaders and traitors have all been vanquished. As a result, the emperor abdicated his throne, passing it on to me-and I can only feel humbled upon receiving such a tremendous blessing. Thinking over achievements and evaluating contributions, at neither day nor night can I forget the devoted and diligent efforts of those persons, which should be celebrated by the nation as a whole. Rewarding and exempting them from taxes has been promptly agreed upon. As for those who died in battle, their families shall be exempted from taxation and rewarded as well.

夫銘功紀勞, 有國之要典; 慎終追舊, 在心之所隆. 自大業創基, 十 有七載. 世路迍邅, 戎車歲動, 自東徂西, 靡有寧日? 實賴將帥竭心, 文武盡効, 寧內拓外, 迄用有成. 威靈遠著, 寇逆消蕩, 遂當揖讓之 禮, 猥饗天人之祚. 念功簡勞, 無忘鑒㸡, 凡厥誠勤, 宜同國慶. 其酬 賞復除之科, 以時論舉. 戰亡之身, 厚加復贈. ${ }^{11}$

Liu Yu thus regarded inscribing the achievements of his generals to be a matter of paramount importance, and he provided broad financial support to relatives of those killed in battle to show that he had not forgotten about those who gave their lives. In the first year of his reign, Liu Yu also issued another imperial decree, which read, 'The families of those who perished in the battlefields and were not able to return home shall be financially supported'. ${ }^{12}$ This empha-

\footnotetext{
11 Song shu 3.53

12 Song shu 54.
} 
sized the importance he attached to the families who survived those who died in battle.

As a result, throughout the entirety of Liu Yu's life, although he had no clear cut belief in religion-and even refused to hold events to pray for spirits to cure disease later in his life when he was terminally ill ${ }^{13}$ - he still strongly backed Meng Yi and Meng Yi's diligent work in service of Buddhism. This is likely on account of Meng Yi's elder brother, Meng Chang 孟永.

Liu Yu was born into extreme poverty, so it is only natural that those who provided him with financial aid when he was poor were later compensated for their kindness. ${ }^{14}$ When Liu Yu first proposed crusading against Huan Xuan, Meng Chang gave all his assets to provide for the army. ${ }^{15} \mathrm{He}$ was also one of the few voices that encouraged him to attack the Southern Yan Kingdom, despite a chorus of voices in opposition. ${ }^{16}$ Ultimately, Meng Chang died as a result of Lu Xun's rebellion. In fact, when an invading army had grown close enough to the capital to pose a viable threat, and the public was nearing a state of hysteria, Meng Chang issued a dying appeal to the masses to risk their lives defending their homes. ${ }^{17}$

After Meng Chang died, Liu Yu wholeheartedly assumed the task of looking after Meng Chang's child so that the boy could inherit his father's post, and he also supported Meng Yi, who was looking after their parents at this time. After first being appointed governor taishou 太守 of Dongyang with no official experience to speak of,

\footnotetext{
13 Song shu 59.

14 For example, Liu Yu was once 30,000 units in debt to Diao Kui Э迋 (?-404)
} with no ability to repay the money, so Diao Kui detained him. Fortunately, Wang Mi 王䍀 (306-407) repaid the debt on Liu Yu's behalf, allowing him to be released. Later, Wang Mi was a chancellor whom Huan Xuan relied on heavily. During Huan Xuan's coronation ceremony, Wang Mi personally held the emperor's jade seal. When Huan Xuan was defeated, many thought Wang Mi should be killed, but Liu Yu went to great lengths to protect him. Cf. Song shu 1.10.

\footnotetext{
15 Jin shu 43.2518.

16 Zizhi tongjian 115.3616.

17 Song shu 1.19.
} 
Meng Yi went on to be appointed governor of Wujun, Kuaiji, and Danyang, one after another. Later, he was appointed chancellor (shizhong 侍中), court official (puye 僕射), and administrator of the crown prince taizi zhanshi 太子詹事, and finally he was once again made provincial governor of Kuaiji. After he died, he was granted the honorific title of left imperial minister of state (zuo guanglu daifu 左 光祿大夫). ${ }^{18}$ By looking over the posts which Meng Yi held throughout his life, one can quickly realize that his history as an official is vastly different than other members of Liu Yu's inner circle, who had all held multiple posts related to military campaigns-whether that meant on the front line or in the rear. In stark contrast, Meng Yi always occupied lucrative posts as a governor or court sinecure.

Later, Meng Yi's son, Meng Shao 孟劭, married Princess Nan Jun 南郡, the sixteenth daughter of Liu Yu; one of Meng Yi's daughters married the Prince of Pengcheng 彭城王, Liu Yikang 劉義康 (409-451), which was the title conferre to one of Liu Yu's sons; and the other married the Prince Ai of Baling 巴陵哀王, Liu Ruoxiu 劉若 休 (447-471), ${ }^{19}$ another son of Liu Yu. In this way, Meng Yi forged familial relations with the royal family of Liu Song.

Careful analysis of available information reveals that Meng Yi's official reputation was actually not very positive, particularly because he often exhibited an arrogant attitude when he served as the governor of Kuaiji 會稽. It was recorded that 'he regards his family as powerful and influential, and he looks down on all other officials' ${ }^{20}$ He was eventually accused of committing a crime and thus relieved of his post ${ }^{21}$-yet the royal family still honoured and pampered him. This fact is likely the result of the tremendous influence his brother, Meng Chang, exerted on the royal family.

Meng Yi did, however, devote himself wholeheartedly to the service of Buddhism, and he put a great deal of effort into the promotion of the Three Treasures. ${ }^{22}$ Most researchers pay little attention

18 Nanshi 19.541-542.

19 Song shu 66.1737.

20 Nanshi 72.1766.

21 Song shu 100.2449. 
to the fact that Meng Yi not only worshiped the Buddha but was also infatuated with talismanic poetic prophecies. According to records from 'Wuxing Zhi' 五行志 (Record of the Five Elements), from History of the Early Song Dynasty (Song shu 宋書), during the time when Sima Yuanxian 司馬元顯 (382-402) consolidated power, Zhu Tanlin 笂雲林, known as Xiangyang Daoren 襄陽道人, wrote a poetic prophecy which read, 'When there is Shiyikou (十一口), and [Huan Xuan] injured by the blades of soldiers, Mugen (木亘), best to cross the Yangtze River, into the vast wilderness'. And there was another that read, 'A weapon of gold has already been made, in Jincheng its lustre shimmers'. Meng Yi provided interpretations for these two poems. ${ }^{23}$ In addition, on the sixth month of the second year of Yongchu (421 CE), of the reign of Emperor Wu of Song, Meng Yi presented the emperor with an auspicious white bird, which had been discovered at Lou County 婁縣 of Wu Commandery 吳郡. On the eighth month of fifteenth year of Yuanjia (438 CE), Meng Yi presented to the emperor a yellow dragon, which had been discovered at the Kuaiji Commandery 會稽郡. ${ }^{24}$ It is clear that, within Liu Yu's inner circle, Meng Yi's role was essentially that of a religious counsellor. As a result, he focused all his energy on graciously and deferentially receiving highly regarded monks and lay Buddhists from home and abroad, such as Sengyi 僧翼 (381-450/451), Chaojin 超進 (380?-473/477), Lanhui 覽慧, Dharmamitra 昙摩密多 (356-442), Kalamyasas 畺良耶舍 (383-442/443), and Juqu Anyang hou 沮渠 安陽莫 (?-464). In total, these visitors amount to no less than nine people, and in Yuhang, Meng Yi also founded the Fangxian Monastery 方顯寺, Fahua Monastery 法華寺, and expanded the Maota Monastery 鄮塔寺. Moreover, the grandest event attributed to Meng Yi was held in 416 after Liu Yu victoriously returned from his campaign in the North with the Former Qin. Meng Yi also invited Buddhabhadra to return to Daochang Monastery in Jiankang (Nanjing) and translate scriptures collectively with such personages as Faxian

\footnotetext{
22 Chu sanzangjiji, T no. 2145, 55: 14.105 a.

23 Liu, 'Gushi de zaisheng', 239-42.

24 Song shu 29.842; cf. Song shu 28.800.
} 


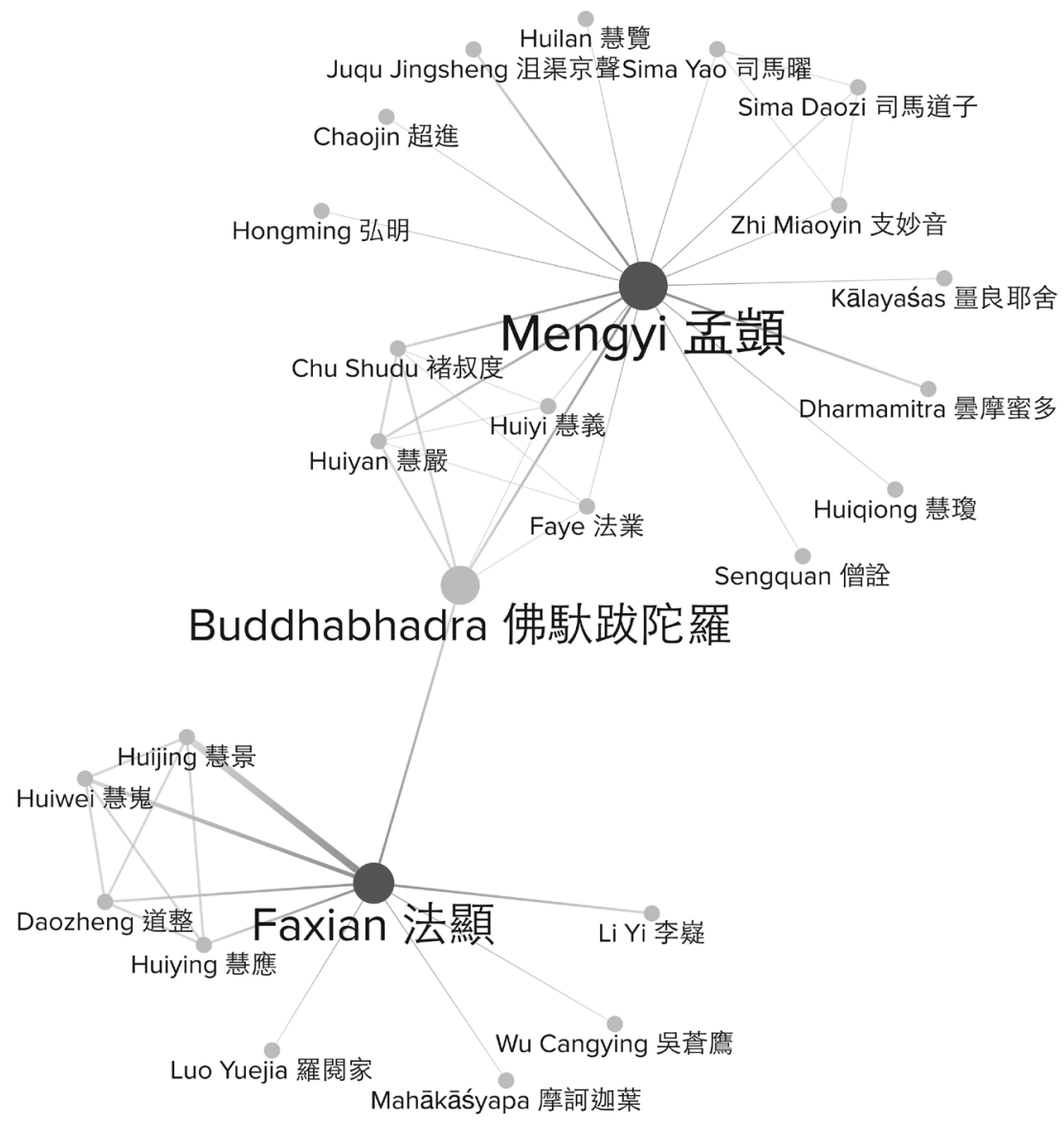

FIG. 1 Diagram of Social Relations Between Faxian 法顯 and Meng Yi 孟顗. Image capture by Wan-chun Chiu.

and Huiguan 慧觀25 (Fig. 1) ${ }^{26}$. Admittedly, these events were related to Meng Yi's personal faith, but they likely exceeded the scope of what his personal power alone could accomplish. It seems a reasonable proposition that these events were tactics used by Liu Yu's inner circle to assist with their war efforts and help establish a new country.

\footnotetext{
25 Song shu 31.919.

26 The diagram of social relations above is based on information produced by the Dharma Drum Institute of Liberal Art's 法鼓山佛教學院 'Visualizing and
} 
The fact of the matter is that the military operations of Liu Yu's inner circle were often accompanied by religious activities. Cejia Songgong Jiuxi Wen 策加宋公九錫文 [Regarding Liu Yu Receiving the Nine Bestowments] praises the moral achievements of Liu Yu, specifically stating that 'recovering the lost lands of the Eastern Jin and protecting the divinity of the emperor were the meritorious deeds of Liu Yu'. ${ }^{27}$ Related research that I personally performed in the past has focused on famous mountains, great rivers, deceased emperors, burial grounds of sages, and ancestral shrines. ${ }^{28}$ However, my research has rarely touched on the topic of Buddhist worship. Additional research revealed that the relationship that initially existed between Liu Yu's inner circle and Buddhism was subtle at best, but after Faxian returned from abroad, various Buddhism projects began to occur, which were inextricably linked to Faxian. This is worth a thorough investigation.

\section{Faxian, Buddhism, and the Political Forces of Qingzhou and Xuzhou}

During the Eastern Jin and the Sixteen Kingdoms period, ethnic groups took control of various parts of the Central Plain, inciting a long lasting struggle over the Huang-Huai River Basin 黃淮流域. Emperor $\mathrm{Mu}$ of Jin (343-361) also repeatedly launched campaigns

Querying Chinese Buddhist Biographies’佛教傳記文學 platform (http://buddhistinformatics.ddbc.edu.tw/biographies/socialnetworks/interface/), accessed on February 20, 2017. This diagram is centred around Faxian and Meng Yi, and it is based upon Liang Gaoseng Zhuan 梁高僧傳 [Biographies of Eminent Monks], Tang Gaoseng Zhuan 唐高僧傳 [Continuation to Biographies of Eminent Monks], Biqiuni Zhuan 比丘尼傳 [Bhikshuni Biographies], Chu sanzang $j i j i$ 出三藏記集 [Compilation of Notes on the Translation of the Tripitaka], and Meisō den shō 名僧傳抄 [Biographies of Famous Monks]. See Appendix One for more details.

27 Nanshi 1.17.

28 Liu, 'San Ling Juanshu'. 
in the North, but his forces were ultimately defeated, and when all was said and done, they returned without any success to speak of. In $410 \mathrm{CE}$, Liu Yu began the process of destroying the Southern Yan, bringing the likes of Qingzhou, Xuzhou, and Yanzhou completely under the rule of the Eastern Jin. ${ }^{29}$ Throughout the process of campaigning against the Southern Yan, resistance of the city occupied by Murong Chao 慕容超, was especially relentless. The city held out for a considerable period of time, and even after the Southern Yan had fallen, Liu Yu was still so furious over the matter that he wanted to completely eviscerate it. However, he let go of this notion after being strongly advised against it. ${ }^{30}$ As the historical records note: 'That year in Donglai (Guanggu City 廣固城), sheets of blood fell from the sky, and at night you could hear the ghosts weeping' ${ }^{31}$

The site of this city was a key post for military transportation that needed to be effectively controlled. And so when it came time to rebuild, Liu Yu's inner circle specially picked Minister Yang Muzhi 長史羊穆之 to serve as the governor of Qingzhou and manage the construction of Dongyang City. ${ }^{32}$ Although there was no biography about Yang Muzhi left behind, he was still acclaimed by a historian as the governor of Qingzhou who was most beloved by his people during the Eastern Jin and Liu Song period. ${ }^{33}$ Half a century later, the work Sishui Zhu 泗水注 [Annotations on the Zi River Records],

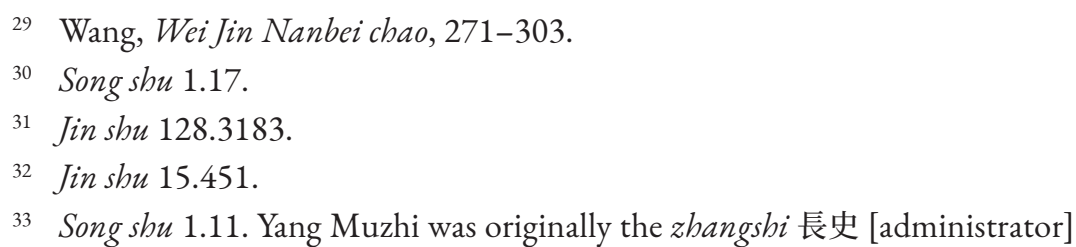
of Xinyu 辛禺, who was then the governor of Yanzhou. In 404, Xin Yu planned a mutiny, so Yang Muzhi beheaded him and sent his decapitated head to the capital. See Nanshi 70: 1700, it is recorded that 'from the Yixi Period to the end of the Liu Song Dynasty, Yang Muzhi was the most talented of all the governors. He was praised by all the officials and people'. Song Yuan Fongzhi congkan 4: 586a, reads:

After Liu Yu captured Guanggu City, Guo Dafu of the state of Qi noticed the quality of feng shui there and persuaded Yang Muzhi to build Dongyang City for Qingzhou. Later, a shrine was built for Guo in front of 
which was compiled in Shuijing Zhu 水經注 [Annotations on the Waterways Classic] by Li Daoyuan 麗道元 (472-527), described Dongyang City as such:

The Yang River comes from the East and flows through Dongyang City's southeast corner. In the Yixi Era, Yang Muzhi, the Eastern Jin's governor of Qingzhou, built this city. Because this city is to the north of the Yang River, it is thus known as Dongyang city.

Li Daoyuan made a point to specially mention Yang Muzhi's meritorious deed of founding the city; at the same time, he also mentioned that the 'most famous monastery', Qiji Monastery 七級 寺, was located near the city, writing:

The Yang River flows from the East, passing by the south of the [former] Qiji Monastery's temple; north of the river is the Buddha palace, which is surrounded by corridors and meandering pavilions that are connected together. Beside the forest are prayer mats scattered across the ground, along with a few staffs and alms bowls that are used by the monks. These are used by strict, prudent monks. They practice a life of Chan meditation in the distant mountains and forests. $^{34}$

It is evident that monks of this monastery engaged in cultivation methods centred around chan meditation. It is also worth examining that this temple was built by Murong De 慕容德 (336-405) during the Southern Yan, and in terms of size, it was likely no smaller than Yongning Monastery 永寧寺, which employed the same Seven Story Pagoda layout and existed later during the Wei Dynasty. ${ }^{35}$ In fact, documents from the period of Emperor Xianwen of the Wei Dynasty (467-470) indicate the 'former' Qiji Monastery had already been

Yunmen Mountain. 劉裕既夷廣固城, 齊人郭大夫相水土, 勸羊穆之築東陽 城為青州. 後人為大夫立廟於雲門山前.

34 Sang, Shuijing zhu sbu, 2234.

35 Wen, 'Qingzhou Fojiao Zaoxiang Kaocha Ji'. 
destroyed on account of a naturally occurring fire. ${ }^{36}$ Thus, although history recorded that after Liu Yu vanquished the Southern Yan he 'eliminated all their local temples', ${ }^{37}$ the truth is that he only destroyed military installations. In contrast, he treated monasteries with respect and protected them. As a result, despite experiencing rule under the Southern Yan, Eastern Jin, Liu Yu, and Wei of the Northern Dynasties, this monastery never suffered any meaningful man-made damage.

Tracing back through history, it is clear that along with the southward migrations following the Yongjia Period, many people relocated to Jiangnan, causing the four states of Xuzhou, Yanzhou, Qingzhou, and Qizhou to become the largest in terms of population and influence. Additionally, the people who moved to the three states of Jinling-Qingzhou, Xuzhou, and Yanzhou-formed the main source of troops for the Beifu 北府 army. ${ }^{38}$ After these events, Xuzhou and Yanzhou in particular formed a strong geopolitical and ancestral relationship with the Eastern Jin and Southern Dynasties that followed. Accordingly, an emotional bond existed between these two regimes and the states of Xuzhou and Yanzhou.

Setting aside the fact that Liu Yu's ancestral hometown is Pengcheng 彭城, the twenty-one generals that attacked the Southern Yan with him, namely, Liu Fan 劉藩, Liu Muzhi 劉穆之, Tan Shao 檀韶,

36 Wei shu 67.1495 records, 'Cui Guang admonished Ling Taihou 靈太 后 [the mother of the emperor] by not climbing to the top of the Nine Layers Pagoda in Yonging 永寧 Monastery', it reads:

In the past, during the Huangxing year, Qiji Monastery stood in Qingzhou. It was both imposing and majestic, but one night it burned down. Despite the predictions of divination and prophecies, we still cannot rid away this bad omen. Things often change over a long period of time; there is absolutely no use in making preparations in advance. The way of heaven is hard to predict, as has been admonished from the past. 去皇興中, 青州七 級, 亦號崇壯, 夜為上火所焚. 雖梓慎、裨䆮之明, 尚不能逆古端兆. 變起倉 卒, 預備不虞. 天道幽遠, 自昔深誡'.

37 Wei shu 97.2131.

38 Tian, 'Bei Fu Bing Shimo', 373. 
Liu Huaishen 劉懷慎, Meng Longfu 孟龍符, Liu Zhong 劉鍾, Yu Qiujin 虞丘進, Kuai En 萠恩, Liu Daolian 劉道憐, Wang Dan 王誕, Liu Jingxuan 劉敬宣, Zang Xi 喊喜 were all descendants from areas around Qingzhou, Xuzhou, and Yanzhou, with the exception of Liu Huaiyu 劉懷玉, Shen Zhongdao 慎仲道, Suo Miao 索邀, Tao Yanshou 陶延壽, Sun Chu 孫處, Hu Fan 胡藩, Liu Cui 劉粹, Wang Yi 王 懿, and Yu Yuezhi 夷悅之. ${ }^{39}$ Thus, after they defeated the Southern Yan, they were especially meticulous in the management of these three states.

In Qingzhou, Xuzhou, and Yanzhou, Liu Yu's inner circle not only established how to handle political and military affairs, but they also acknowledged and conformed to the area's religious customs. This is because the region of Xuzhou and Haizhou had been an important route for the acceptance and propagation of Buddhism from the Eastern Han Dynasty onward. It was here that the earliest monasteries were set up, ${ }^{40}$ and more importantly, it was here that prominent monks from abroad stayed-such as Yan Fodiao 嚴佛 調 of the Eastern Han period who wrote Shami shibui zhangju 沙 爾十慧章句 [Ten Pieces of Wisdom by Lowly Monk], a work that proclaimed the fundamental teachings of Hinayana Buddhism and made reference to practicing changuan 禪觀 meditation. ${ }^{41}$ Another example is the monastic group of Senglang 僧朗 at Mount Tai during the Eastern Jin and Sixteen Kingdom's period. Sovereigns of the Former Qin, Eastern Jin, Later Yan, Southern Yan, and Southern Wei

\footnotetext{
39 Wang, Wei Jin Nanbei chao, 300-01.

40 During the Eastern Han Dynasty period, Liu Ying 劉英 (29-71) was known
} by the title of Prince of Chu 楚王 and praised noble Buddhist monasteries, and Ze Rong 笮融 (?-196) established many monasteries throughout Xuzhou. See Zhang, Han Tang Fosi, 22-23.

41 Gaoseng zhuan, T no. 2059, 50: 324; additionally, 'Shihui Zhangju Xu'十 慧章句序, Chu sanzang ji ji, T no. 2145, 55: 10.70a2: '(The principle of Shihui are) spread far and wide through the cosmos and can help practitioners with their cultivation' (十慧之文) 廣彌三界, 近觀諸身. It is clear that this work is related to changuan meditation. Ren, Zhongguo Fojiao shi, 146; Zhang, 'Mile Xinyang Shu Pin', 534. 
all preferentially treated and revered this group, ${ }^{42}$ and they founded large monasteries for the group as well-especially Langgong Monastery. Specifically,

On behalf of Senglang, Murong De, Emperor of the Southern Yan, carried out the construction [of Langgong Monastery].... Murong De provided Senglang with tribute from three counties in order to build this monastery. The monastery was composed of a few dozen Buddha structures, both big and small. Corridors extended for a thousand metres. The monastery experienced three campaigns to eradicate Buddhism, and yet it remains standing. ... Since ancient times, this monastery has been called 'Langgong Monastery' 朗公寺 on account of its efficaciousness. As a result, it is revered by all people. ${ }^{43}$

It is evident from this that belief in Buddhism was nearly universal in this region. ${ }^{44}$ After Liu Yu conquered Chang'an and destroyed the Later Qin, monks in the Guangzhong region went east to Xuzhou and Haizhou. Kumārajīva’s 鳩摩羅什 (344-413) disciples, Daorong 道融 and Sengsong 僧嵩, went to the Pengcheng region to preach. ${ }^{45}$ There, Sengyuan and other monks were taught about the Satyasiddhisástra 成實論 and Abhidharma 毘曇 by Sengsong. ${ }^{46}$ In this way, Pengcheng and Shouchun became bases of operations for the Hinayana Free School during the Northern and Southern dynasties period. ${ }^{47}$ As for the attitude of Liu Yu's inner circle toward Buddhism, by and large they maintained an air of reverence, and they safeguarded the religion, especially during the campaigns to extinguish Buddhism during the Northern Dynasties (446-452). Sengdao 僧導 (362-457) took in a good number of monks who were fleeing, and he also respectfully burned offerings for the deceased in an act of mourning. ${ }^{48}$

\footnotetext{
42 Miyagawa, Rikuchō-shi kenkyū, 255-78.

43 Xu Gaoseng zhuan, T no. 2060, 50: 10.506.

44 For further details, see Lin, 'Hongming ji', 82-85.

45 Gaoseng zhuan, T no. 2059, 50: 6.363.

46 Gaoseng zhuan, T no. 2059, 50: 7.375.

47 Tang, Han Wei Liangjin, 491-526.
} 
Just after Faxian returned to his native country, he went to Pengcheng, and although he only resided there for a short period of time, he nonetheless left a tremendous impact. According to records from Record of the Buddha Land, after Faxian arrived at the shores of Laoshan 牢山, he was received by Li Yi 李峘, governor of Changguang Jun 長廣郡. Afterwards, he received an invitation from the governor of both Qingzhou and Yanzhou to stay for the winter through the summer. ${ }^{49}$ The biography regarding Liu Daolian, contained in History of the Early Song Dynasty, recounts that his post was changed to governor of North Xuzhou 北徐州 in 411, which moved his garrison to Pengcheng. In 412, when Liu Yu attacked Liu Yi, he appointed Liu Daolian as martial governor of Yanzhou and Qingzhou. Liu Daolian was later responsible for administering the military affairs of Jinling 晋陵, Jingkou 京口, and Huainan 淮南, and he also governed Yanzhou and Qingzhou. ${ }^{50}$ Scholars use this evidence as proof that Liu Daolian invited Faxian to spend the winter through summer in Qingzhou; that is to say that the one called 'Liu Yun 劉㳘 of Qingzhou' 青州 who invited Faxian to stay there from the winter to summer was indeed Liu Daolian. ${ }^{51}$ Furthermore, during the time which Faxian stayed in Pengcheng, he established Longhua Monastery 龍華寺 in accor-

48 Gaoseng zhuan, T no. 2059, 50: 7.375:

Later when a monastery was founded at Shouchun, it was also called Dongshan Monastery. He often explained Buddha scriptures and theories to the masses there, and over 1,000 people followed him there to study. During the campaigns to eradicate Buddhism, several hundred monks went to where he was, seeking refuge. Sengdao provided all of them with clothes and food. Sengdao held Buddhist ceremonies in honour of the monks that had been killed and wept for them. 後立寺於壽春, 即東山寺也. 常講說經 論, 受業千有餘人. 會虜俄滅佛法, 沙門避難, 投之者數百, 悉給衣食. 其有 死於虜者, 皆設會行香, 為之流涕哀慟.

49 Zhang, Faxian zhuan jiaozbu, 147-48.

50 Song shu 51.1462.

51 Rao Zongyi did some textual research on the two footnotes that read 'Liu Yun of Qingzhou' and 'invited Faxian to stay from the winter to summer' from 
dance with the Longhua $T u$ 龍華圖 [Longhua Image]. This matter is recorded in Sishui Zhu 泗水注 [Annotations on the Si River Records], in Shuijing Zhu 水經注 [Annotations on the Waterways Classic] by Li Daoyuan 蹢道元 (?-527), which reads:

The Si River moves southeast, moving through the northeast of Pengcheng (Xuzhou). To the west of the river is Longhua Monastery. This monastery was the first designed according to the Longhua Image, which was brought back from India by Faxian, after he returned by boat. Faxian was the first person in China to produce such a monastery. The emergence of these types of monasteries in China began with Faxian. When Faxian returned, he brought two stones back with him. These are still within the southern foundation of Longhua Monastery. With a bright surface that is clean to the eye, these stones have garnered people's admiration.

(泗水) 又東南過彭城(徐州) 東北, 泗水西有龍華寺, 是沙門釋法顯 遠出西域, 浮海東還, 持《龍華圖》, 首創此制, 法流中夏, 自法顯始 也. 其所持天笂二石, 仍在南陸東基堪(俞)中, 其石尚光潔可愛.52

Regarding the contents and essence of the Longhua image 龍華圖, scholars have different opinions. Some of them believe it depicted the Maitreya Buddha attaining enlightenment beneath the Hualin Tree in the Longhua garden. ${ }^{53}$ Others believe the image depicted offerings to Mile Fo jing 彌勒佛經 (Maitreya Buddha Sutra), as described in the sutra. Apparently, it featured two large flower wrapped treasures in the sky, and the Kings of Nagas performed refined music and gestures in the image-beautiful flowers bloom out of their mouths and petals rain from their pores, depicting an ideal scene of offerings being presented to the Buddha. ${ }^{54} \mathrm{~A}$ third explanation contends that

Zhang Xun's Faxian Zhuan Jiaozbu. See Zhang, Faxian zhuan jiaozhu, 148;

Rao, 'Zaoqi Qingzhou Cheng yu Fojiao', 52-53.

52 Sang, Shuijing zbu shu, 2144.

$53 \mathrm{Su}$, Zhongguo shiku si, 187.

54 Rao, 'Zaoqi Qingzhou Cheng yu Fojiao', 52. 
besides being a manifestation of Rebirth Maitreyanism, the image was also a diagram of Indian Buddhist monasteries, and Longhua Monastery was the first Buddhist monastery on Chinese soil to be built according to such a diagram. ${ }^{55}$ Besides indicating that the Longhua Image and the Maitreyanism Image are related, the third explanation also adds a new idea to the mix - that the Longhua Image provided a diagram of Indian monasteries. As for the implication that it was 'first designed [according to the Longhua Image]', there remain two possible ways in which one could interpret this phrase. It is clear, though, that given the materials currently available it remains difficult to reach a final conclusion.

Despite this, we can already confirm that Faxian personally saw images of the Maitreya Buddha when he was seeking scriptures in India and also personally heard an oral version of the Mile jing 彌勒 經 [Maitreya Sutra]. Record of the Buddha Land also records a mystical legend about the Maitreya image:

There is a small state named Darada 陀歷. The monks in this state all study Hinayana Buddhism. There is an Arhat in this state with remarkable abilities that sent a craftsman to Tusita. There, the craftsman saw the appearance of the Maitreya Bodhisattva, and upon returning they used a block of wood to carve a statue of Maitreya. The craftsman was sent to Tusita about three times before he was able to make a consummate statue. This statue is eight $z$ hang tall, and the feet of Maitreya are eight chi long. On days when they fast, the statue often glows. The rulers of many states were eager to come here and make offerings to the statue. Currently, this statue is still in the same state.

有一小國名陀歷, 亦有眾僧皆小乘學, 其國昔有羅漢, 以神足力將一 巧匠，上自率天觀彌勒菩薩長短色貌，還下刻木作像，前後三上觀， 然後乃成像, 長八丈足跌八尺, 齋日常有光明, 諸國王競興供養, 今 故現在於此. ${ }^{56}$

\footnotetext{
55 Wang, 'Faxian yu Mile xinyang', 176.

56 Gaoseng Faxian zhuan, T no. 2085, 51: 857a.
} 
In Darada, Faxian saw the image of the Maitreya Buddha with a glow that extended for eight zhang. An arhat used his supernatural powers to send an artisan to Tusita three times. This allowed the artisan to depict Maitreya visually. Typically speaking, a person would have to engage in self-cultivation for a long period of time before they could see the true form of Maitreya, but after this image was brought to the human realm it was thus worshipped by all the kings. Moreover, Faxian also spent over two years living in Tāmralipti, transcribing Buddhist texts and making copies of Buddhist images. He even tried writing down the Mile jing, which had been orally transmitted by masters in the Indian subcontinent. ${ }^{57}$ It is thus clear that he was extremely interested in the content of the Mile Jing, especially the practices of the Maitreyanism faith. These practices are related to holding on to precepts (shoujie 守戒), reciting the Buddha's name (nianfo 念佛), and stabilizing meditation (zhiguan 止觀), and the content of the Mile jing is also identical in nature to the translations of texts he later engaged in. We can from this infer that the building Longhua Monastery in Pengcheng and the Longhua Image are both intimately related to Rebirth Maitreyanism, the faith of Maitreya being reborn down into the world.

Previous research has already produced abundant material on Maitreyanism during this period in China. ${ }^{58}$ Simply put, Maitreyanism in Han regions originates from India. Early Buddhist sects in India had a theory that Maitreya is the Buddha of the future. Accordingly, the Aban jing 阿含經 (Aggama Sutra) from the early period of sectarian Buddhism already spoke of Maitreya. ${ }^{59}$

That said, by looking through Pure Land Buddhist classics, we

57 Gaoseng Faxian zhuan, T no. 2085, 51: 863a.

58 Wang, Mile Xinyang Yanjiu, 6-18, provides a detailed explanation of this.

59 Examples include Gautama Sanghadeva's (Qutan Sengqietipo 翟昙僧伽提 婆) translation of 'Wang Xiangying Pin Yi' 王相應品一 from juan 13 of Zhong Ahan jing 中阿含經 (Skt. Madhyamagama). See T no. 26, 1: 508-511; and Gautama Sanghadeva's translation of 'Deng Yue Sidi Pin Ershi Qi' 等趣四諦品二十 七 from juan 19 of Zengyi aban jing 增壹阿含經 (Skt. Ekottara-ägama), collected in $T$ no. 125, 2: 645 . 
can see that the six scriptures on Maitreya of Mahayana Buddhism began to emerge during the Western Jin dynasty, and they contain a considerable amount of information concerning the Pure Land notion. There are three of note: the Mile xiasheng jing 彌勒下生經 [Maitreya Rebirth Sutra; Skt. Maitreyavyākarana], Mile chengfo jing 彌勒成佛經 [Maitreya Attaining Buddhahood Sutra], and Mile shangsheng jing 彌勒上生經 [Maitreya Ascending Sutra]. These three scriptures had a rather large impact on China at that time, and they are referred to collectively as the 'Mile sanbu jing' 彌勒三部經 [Three Scriptures on Maitreya]. ${ }^{60}$ These introduce the innate causes and conditions of Maitreya, Maitreya's previous and coming life, Maitreya's attainment of Buddhahood, the three assemblies under the Longhua Tree, and more. Generally speaking, virtually everything within these texts can be considered important information regarding the Maitreyanism faith.

It was during the Jin Dynasty that Maitreyanism began appearing in China. This began largely on account of the translation of scriptures about Maitreya, such as the 'Three Scriptures on Maitreya', and the belief is a subset of belief in the Pure Land. By the Northern and Southern dynasties period (420-589), Maitreyanism was already widely popular. Considering documents related to Maitreya that were produced in China, Maitreyanism can be roughly divided into Ascending Maitreyanism (上生) and Rebirth Maitreyanism (下生). Believers of Ascending Maitreyanism believe that that the Maitreya Bodhisattva expounds on Dharma in Tușita Heaven. As a result, these believers want to be reborn into the fourth of the six devas of Kamadhatu-Tusita, where they can receive instructions from Maitreya and attain enlightenment. Believers of this include such figures as Dao'an 道安 (314-386), Dai Yong 戴顒 (378-441), Faxiang 法祥 (lifespan unclear), Huiyan 慧嚴 (363-443), Fasheng 法盛 (347-461), and Tanfu 昙副 (?-497) ${ }^{61}$ (see

\footnotetext{
60 Yang, 'Hanyi Fojing Zhong'.

61 Gaoseng zhuan, T no. 2059, 50: 352; on Dai Yong, see Fayuan zhulin, T no. 2122, 53: 16.406; on Faxiang, see Meisō den shō 28.359; on Fasheng and Tanfu see Meisō den shō 27.359 .
} 
Appendix Two). As for Rebirth Maitreyanism, its believers firmly believe that 5,670,000,000 years after the Buddha attains nirvana, Maitreya will descend from Tusita and be reborn into the human realm, where Maitreya will become a monk, study Buddhism, gain enlightenment under the Longhua Tree in the Hualin Garden of Chitou city, and then hold three assemblies wherein he teaches people how to attain liberation. At this time, people who were not able to obtain enlightenment from the Śākyamuni Buddha's teachings will be able to use Maitreya's teachings to attain enlightenment. Believers of Rebirth Maitreyanism also believe that they can be reborn into Tusita, receive instructions from Maitreya, and attain Buddhahood. Such believers of this include Emperor Ming of Liu Song 劉宋明帝 (439-472), Zhou Yong 周顒 (422-483), Xiao Ziliang 蕭子良 (460-494), Huisi of Nanyue 南嶽慧思 (515-577), and others. ${ }^{62}$

62 There is a great deal of existent research. See Bai, Zhongguo shiku si yanjiu; Zhang, 'Nianfo Jingtu', 83. Additionally, 'Fayuan Zayuan Yanshi Ji Mulu Xu'法 苑雜緣原始集目錄序 [Preface to the Catalog of Primary Karmic Beginnings] collected in the twelfth juan of Chu sanzang ji ji 出三藏記集 [Compilation of Documents on the Translation of the Tripitaka] contains three articles describing Rebirth Maitreyanism: 'Songming Huangdi chuzao Longhua shiyuan wen’ 宋明 皇帝初造龍華誓願文 [Text on Emperor Ming of Liu Song’s Initial Writing of the Longhua Faith], 'Jingshi Zhuyi zao Mile xiang sanhui ji’ 京師諸邑造彌勒像三會 記 [Record of the Establishment of the Maitreya Image of the Three Assemblies across the Capital and Villages], and 'Qi Jingling Wenxuan wang Longhua hui ji' 齊竟陵文宣王龍華會記 [Record of Longhua Assembly convened by Prince Jingling of the Qi], by Emperor Ming of the Song (Liu Yu 劉或 [439-472]), Zhou Yong 周顒 (?-493), and Xiao Ziliang 蕭子良 (460-494), respectively.

Moreover, Xu Gaoseng zhuan 續高僧傳 (T no. 2060, 55: 562) contains this record about Huisi:

Huisi dreamt that Maitreya and Amitabha provided him with lectures of Dharma, and as a result, he attained enlightenment. Consequently, he had two statues made of Maitreya and Amitabha, and he made offerings to both of them. In his dream, he also saw himself along with Maitreya and other deities assembling under the Longhua tree. In his heart, he thought 
A good number of the core members of Liu Yu's inner circle were devout Buddhists, especially those from the south-eastern Binhai Region 濱海區 who believed in the Guanyin Bodhisattva. Such believers include Mao Dezu 毛德祖 (365-429) and Wang Shaozhi 王韶之 (380-435). ${ }^{63}$ There was also Fu Liang 傅亮 (374-426), ${ }^{64}$ a figure in Liu Yu's inner circle with literary prowess, and both he and his sons were believers in the Guanyin Bodhisattva. In particular, after experiencing the chaos of Sun En's rebellion (399-411), they pieced back together the then fragmented Guanshiyin yingyan ji 觀世音應驗記 [Record of Numinous Manifestations of the Bodhisattva Avalokiteśvara] with the hope of inspiring

'after the Śākyamuni Buddha reached nirvana, I had no way to accept the faith of the Lotus Sutra, but now with the help of the Maitreya Buddha's compassion I have been able to attain enlightenment'. As a result, Huisi cultivated himself diligently. He also had a bottle filled with water placed in front of the Buddha statues, so he could have all his arrangement for offerings done appropriately. 夢彌勒爾陀, 說法開悟, 故造二像, 並同供養, 又夢 隨從彌勒與諸眷屬, 同會龍華. 心自惟日，“我於釋迦末法受持法華，今值慈 尊, 感傷悲泣, 豁然覺悟. '轉復精進, 靈瑞重沓, 瓶水常滿、供事嚴備.

63 Regarding Mao Dezu's 'the whole family chanted the name "Guanshiyin” together matter', see Zhang Yan 張演 (active 430s), ‘Mao Dezu’ 毛德祖, in Guanshiyin yingyan ji 觀世音應驗記 [Records on Numinous Manifestations of the Bodhisattva Avalokiteśvara], section 8 (Dong, Guanshiyin yingyan ji sanzhong, 52). Also consult Lu Gao’s 陸杲 (459-532) 'Wuxing Jun Shi' 吳興郡吏 [an official of Wuxing Region], in Ji Guanshiyin yingyan ji 繫觀世音應驗記 [Additional Records on Numinous Manifestations of the Bodhisattva Avalokiteśvara], section 3: 66, which reads, 'This minor had no belief in Buddhism to speak of, but he everyday listened to Wang Shaozhi 王韶之 recite the names of Avalokiteśvara' 此吏素不事佛, 但恒聞王(韶之)道光世音.

64 Fu Liang's 傅亮 (374-426) biography in Song shu 43.1337, Sheng Yue writes: 'Just after Liu Yu took the imperial throne, all of his documents were drafted by Teng Yan 滕演, a military official. When Liu Yu went north to campaign at Guanggu City, all of his documents were drafted by the zhangshi Wang Dan 王誕 (375-413). Later, all of Liu Yu’s documents were composed by Fu Liang'. 
belief in more people. ${ }^{65}$ On the other hand, belief in Maitreyanism during the Eastern Jin and Sixteen Kingdoms was mainly spread throughout Buddhist groups in Xiangyang and Chang'an. Liu Yu's inner circle, however, was principally based around Qingzhou and Yanzhou, thus raising the question as to whether or not Liu Yu's inner circle ever came in contact with Maitreyanism. Today we can see that certain people in their inner circle, such as Jiang Yi 江夷 (384-431) of Jiyang 濟陽, likely started off believing in the Guanyin Bodhisattva but later became a believer of Maitreya. ${ }^{66}$ In Mile pusa zan 彌勒菩薩讚 (Praise of Maitreya Bodhisattva), Fu Liang 傅亮 wrote,

Time has no distinction between before and after; there is a sole truth that cannot be divided. Dragons fly through Tuṣita as Maitreya waits to descend to the world and be born into the human realm. Long nights are just as long; we long and thirst for Maitreya. From day to night we think of jubilation, imagining the day when Maitreya arrives.

${ }^{65}$ Fu, 'Guanshiyin'. Additionally, 'Shamen Zhu Fayi' 沙門笂法義 (307-380) [Monk Zhu Fayi], the seventeenth section ze 則 of this work mentions how his father once heard a monk named Fayi tell him about how Avalokiteśvara used a knife to dig in to a person's stomach and eradicate a disease within. See Dong, Guanshiyin yingyan, 25.

${ }^{66}$ In 'Xiuxin fu xu' 修心賦序, Jiang Zong 江總 (519-594) personally declared that Longquan Monastery was established by Jiang Yi in $437 \mathrm{CE}$; see Chen shu 27.344. Fozu tongji 佛祖統紀 36.343c records the legend of Jiang Yi producing a statue. See entry on 'Dai Yong' in Appendix Two.

Such a legend should not be believed, but it contains information about a kind of faith during that period. Even if this is actually not related to Jiang Yi, during this period scholar officials initially believed in Guanyin, but later-after people began converting on account of the influence of Maitreya-they likely followed suit. This is perhaps the truth. That said, the time when this occurred should be assumed to be after the establishment of the Liu Song Dynasty. 
時無並後, 道不二司. 龍潛兒率, 按縸候時. 殹㗨長夜, 懷而慕思. 思 樂朗旦, 屬想靈期. ${ }^{67}$

It is not clear exactly when this writing of praise was composed, but as Fu Liang died in 426, it was certainly composed no later than this. Among it, the sentence 'Dragons fly through Tuṣita as Maitreya waits to descend to the world' means that Maitreya is waiting to descend to Earth from Tusita, and the latter half of 'long nights are just as long; we long and thirst for Maitreya' expresses a longing for the imminent arrival of Maitreya. It is thus clear that this can be classified as Rebirth Maitreyanism thought. As for this figure that they long for, this Maitreya that will come into the world and become a Buddha-is it really just referring to a Buddha that will arrive in the future or is there a political implication here? I will not offer up an interpretation about this.

Such examples of writings that praise Maitreya are examples of the universality of Maitreyanism. In truth, even earlier during the Jin Dynasty, the famous monk Zhidun 支遁 (314-366) wrote Mile zan 彌勒讚 [Praising Maitreya], which read:

Maitreya possesses a divine position. His deeds were recorded in Buddhist texts. A dragon soars through the air in Tusita, and Maitreya is solemnly situated above all the deities. The sound of Dharma reverberates through the celestial palace, and it can be heard throughout the vast cosmos. ... Maitreya possesses thirty-two dignified characteristics that glisten and dazzle the Hualin Garden. As the eternal wheel of Dharma slowly moves forward, Maitreya holds three assemblies here, lecturing over the essence of Dharma.

彌勒承神第, 聖錄載靈篇. 乘乾因九五, 龍飛自率天. 法鼓震玄宮, 逸 響亮三千.... 挺此四八姿, 映蔚華林園. 亶畳玄輪奏, 三攄在昔緣. 68

${ }^{67}$ Fu Liang, 'Mile pusa zan', Quan Song Wen, Quan Shanggu Sandai Qin Han Sanguo Liuchao wen 26. 2578a.

68 Zhidun, 'Mile zan', Quan Jin wen, Shanggu Sandai Qin Han Sanguo Liuchao wen 157.2370-71. 
Here, the praises of Maitreya accept the prophecy of the Sakyamuni Buddha, becoming the Bodhisattva to inherit the position of the Buddha, rise up to the heavenly realm of Tuṣita 兒率天宮, and explain the Dharma to the masses. The last four sentences are describing the thirty-two characteristics of the Maitreya image, reflecting the flourishing Hualin Garden 華林園 as well as anticipation for future karmic results. From this we get a reflection of the circumstances surrounding the spread of early Maitreyanism belief in the south of China. This understanding of Maitreyanism is mainly based on written scriptures, and it can be classified as Rising Maitreyanism. This work can be contrasted with another work of the same name, the Mile zan 彌勒讚 [Praising Maitreya] by Shen Yue 沈約 (441-531) of the Liang Dynasty period, which was composed on the occasion of the crown prince having a stone statue of the Maitreya built, it reads:

The vast river flows from far away, covering a near endless path. Religions have fixed deities that should be worshipped, yet deities are without fixed functions. Maitreya will not long for a princely family, and instead will join the Sangha to engage in self-cultivation and assume divine tasks. The sun of wisdom rises early in the morning; fragrant rain falls to the ground in the evening. A reliance on faith in Maitreya presents a shared, predestined fate that brings us here. This is our divine Maitreya. He is just as important as heaven. Beneath the Longhua Tree, he will lecture over Buddhist scripture. His beautiful words will fill people's hearts with incomparable joy. ... The present writer records such wonderful words about Maitreya, hoping they can have a far-reaching impact.

眇眇長津, 遙遙避拿. 道有常尊, 神無恆器. 脫㞞王家, 來承寶位. 慧 日晨開, 香雨霄墜. 藉感必從, 憑緣斯至. 日我聖儲, 儀天作蔶. 尚相 龍柯, 瞻言思媚. ... 敬勒玄蹤, 式傳遐憙. ${ }^{69}$

Crown Prince Zhaoming 昭明 had asked Shen Yue to write praise

69 Shen Yue, 'Mile Zan', Quan Liang Wen, Quan Shanggu Sandai Qin Han Sanguo Liuchao wen 30: 3127-1. 
of the Maitreya stone statue he had constructed. Two parts in particular-'Maitreya will not long for a princely family, and instead will join the Sangha to engage in self-cultivation and assume divine tasks' and 'beneath the Longhua Tree, he will lecture over Buddhist scripture. His beautiful words will fill people's hearts with incomparable joy'-indicate that he was praising the Maitreya Bodhisattva's eventual decision to be reborn into this realm where he will not care about being a prince and instead leave his home to study Buddhism, later receive teachings beneath the Longshu tree, attain enlightenment, and finally explain the true principles of Dharma to the people.

Another work worth considering is the later Liang Huang chan 梁皇懺 [Rituals of Repentance by the Emperor (Wu of the) Liang], which begins as such,

The four-character word of 'Compassion Site' was chosen because it was realized in a dream. When the Maitreya Buddha descends from Tusita into the human realm, his compassion will extend for all the kalpas that follow. Using the deeds of Maitreya to write this name, one should not dare to rashly make alterations.

This texts makes it clear that such repentance is because the writer was inspired in a dream to visit the Maitreya Buddha and thus established the name 'Compassion Bodhimanda 慈悲道場'. At the same time, the order in which one should worship all the Buddhas is also clear here; all worship starts with the 'Maitreya Buddha', only after comes the 'Master Śākyamuni 本師', and then all other Buddhas. Moreover, before worshiping you should first recite, 'I devote myself to the compassionate and benevolent father, Maitreya'.70

70 There is a great deal of discussion as to when Liang Huang chan was produced. Recently a final consensus has more or less been reached that the text was produced sometime around the late Northern and Southern dynasties period, or the early period of the Sui Dynasty. In terms of content, the work is consistent with the defining characteristics of methods of repentance from the Southern Dynasties, and it is also consistent with the ways in which Emperor Wu of Liang 
It is clear that in the fifth and sixth centuries, belief in Rebirth Maitreyanism flourished. What remains uncertain is just how the original Rising Maitreyanism turned into Rebirth Maitreyanism between the end of the fourth Century and the early fifth Century. Currently, the only clear document pertaining to this question is that which described the Maitreya Image 彌勒像 and Longhua Image as brought back to China by Faxian.

It appears from this that Liu Daolian, who was the highest-ranking official of that region, personally greeted the prominent monk Faxian after he returned from seeking scriptures abroad. Faxian also brought back with him images and a prophecy that peace and joy would be delivered by the eventual three assemblies at Fahua, and Liu Daolian was certainly very interested. These notions also fit with the near universal psychological demands of the people and soldiers following a long period of warfare. Additionally, support for the establishment of Fahua Monastery contributed to the regional propagation of Rebirth Maitreyanism-especially since Liu Daolian and Faxian spent a winter through a summer together there, which likely provided Liu Daolian with a deep understanding of Faxian's feelings of zeal and urgency for translating Buddhist texts. As a result, Liu Daolian also supported Faxian's decision to head south toward Jiankang and translate scriptures, which also caused Rebirth Maitreyanism to have a greater direct influence on the Jiangzuo 江左 region.

\section{Faxian and the State of Buddhism and Political Power in Jingzhou}

As the Western Jin dynasty's control over the Central Plain disintegrated, educated bureaucrats and civilians from the North moved to the South in hordes. Thus, during the Eastern Jin and Southern

worshipped the Buddha. However, the order in which it worships all the Buddhas is different from customs which followed the Tang Dynasty, thus it can be confirmed that the Liang Huang chan was likely produced during the Liang Dynasty. See Xin, 'Liang Huang baochan', 53-55. 
Dynasties period, Han Chinese culture continually developed in the Jiangnan region, and it gradually formed into three regions of developed culture: first is the area centred around the Great Lake 太湖 Plain and the Ningshao 寧紹 Plain, which includes Jiankang 建康, Wu Jun 吳郡, and Kuaiji Jun 會稽郡, Great Lake Tai 太湖, and the Ningshao 寧紹 Plain; second is the Xunyang 潯陽 and Yuzhong 豫章 regions surrounding Poyang Lake 鄱陽湖; third is the Dongting Lake basin and the area surrounding the Jiangling 江 陵, Jiangxia 江夏, and Changsha 長沙 regions. These developments led to the formation of cultural centres around Jiankang, Kuaiji, Wujun, Xunyang, Nanjun, Jiangxia, and Changsha. ${ }^{71}$ In fact, the formation of these three areas of developed culture is related to the special political and societal structures of that time: namely, the scale and routes of immigration, the layout of the Eastern Jin in the South and the southern dynasties that followed, and the unique political situation of Jingzhou and Yangzhou. Moreover, this is all also closely related to economic development within southern society. Specifically, the Jingzhou region was prominently located in the middle reaches of the Yangtze River, allowing it to hold a tight grip over the political situation of Jiangzuo, and it was also in the frontline of the confrontation between the North and South, facilitating frequent communications between the North and South. As a result, this area's culture was particularly prosperous, especially Jiangling, which was completely under the control of Jingzhou, and a mecca for traveling merchants and intellectual persons. This caused Buddhism in Jingzhou, which initially had very few monks, ${ }^{72}$ to undergo remarkable growth. During this time, many prominent monks from abroad came to reside in the Jiangling region, including the monk central to the paper's discussion-Faxian-who spent his final years here. Others such as Dharma-yaśas (Tanmoyeshe 曇

71 In Ruxue Chuanbo, Xia Zengmin 夏增民 examines the formation of a new Confucian cultural region during the Eastern Jin and Southern Dynasties. But this area is actually not limited to Confucianism, for it is really a cultural mecca in a broader sense.

72 Zhang, Hubei lishi wenhua dili, 26-31. 
摩耶舍), Vimalākṣa (Pimoluocha 卑摩羅叉), Guṇabhadra (Qiunabatuoluo 求那咙陀羅), and Tanyi mingled with famous people, lectured over texts and Buddhism, and even amassed disciples and promoted Buddhism. During this period, more Buddhist monasteries were founded in the Jiangling region, continuing the tradition established by important Buddhist cities in the region, such as Chang'an and Jiankang, which subsequently became eminent cities. Monasteries of this region that are featured in the greatest amount of historical records include Xin Monastery, Changsha Monastery, Shangming Monastery, Pipa Monastery, and Zhulin Monastery. ${ }^{73}$

The fact of the matter is that the development of Buddhism in Jingzhou was closely related to the inner circles of Dao'an and Huiyuan. Dao'an's Xiangyang Buddhist group split at that time, but this actually helped the later development of Buddhism in Jiangling, Chang'an, and Lushan (Fig. 2). We can surmise that 378 was when events that most directly led to this split occurred, for it was in this year that Fu Pi 符丕 travelled from the North to the South with his troops, bringing warfare to Xiangyang. Tanyi had formerly been a disciple of Dao'an, and as a result he was invited to leave Xiangyang and go to Jiangling by Teng Hanfang 滕含方, the governor of Changsha, who had him put in charge of Changsha Monastery. When Xiangyang found itself surrounded by enemy troops, Dao'an was also placed in an extremely difficult position. In the end, he disbanded his disciples and followers, telling them they could go where they liked. ${ }^{74}$ As a result, a great number of Dao'an's disciples headed south to Jiangling. Among them, those who passed through and stayed at Changsha Monastery include Fayu 法遇 and Tanjie 曇戒 (328-397); those who stayed at Shangming Monastery include Zhu Sengfu 竺僧敷 (285-323), Tanhui 曇徽 (323-395), Huiyuan, and Huichi 慧持 (337-412). Shi Huiyong (332-414) had already gone

73 Yan Gengwang 嚴耕望, Wei Jin Nanbei chao Fojiao, 130-31, produced a preliminary outline of the situation of Buddhist temples and monks in Jiangling during the Wei, Jin, and North-South dynasties period.

74 Xia, 'Buyi Guowang', 215-17, which contains a thorough analysis of the statement 'propagating Buddhism' 教化之體, which Dao'an disseminated. 


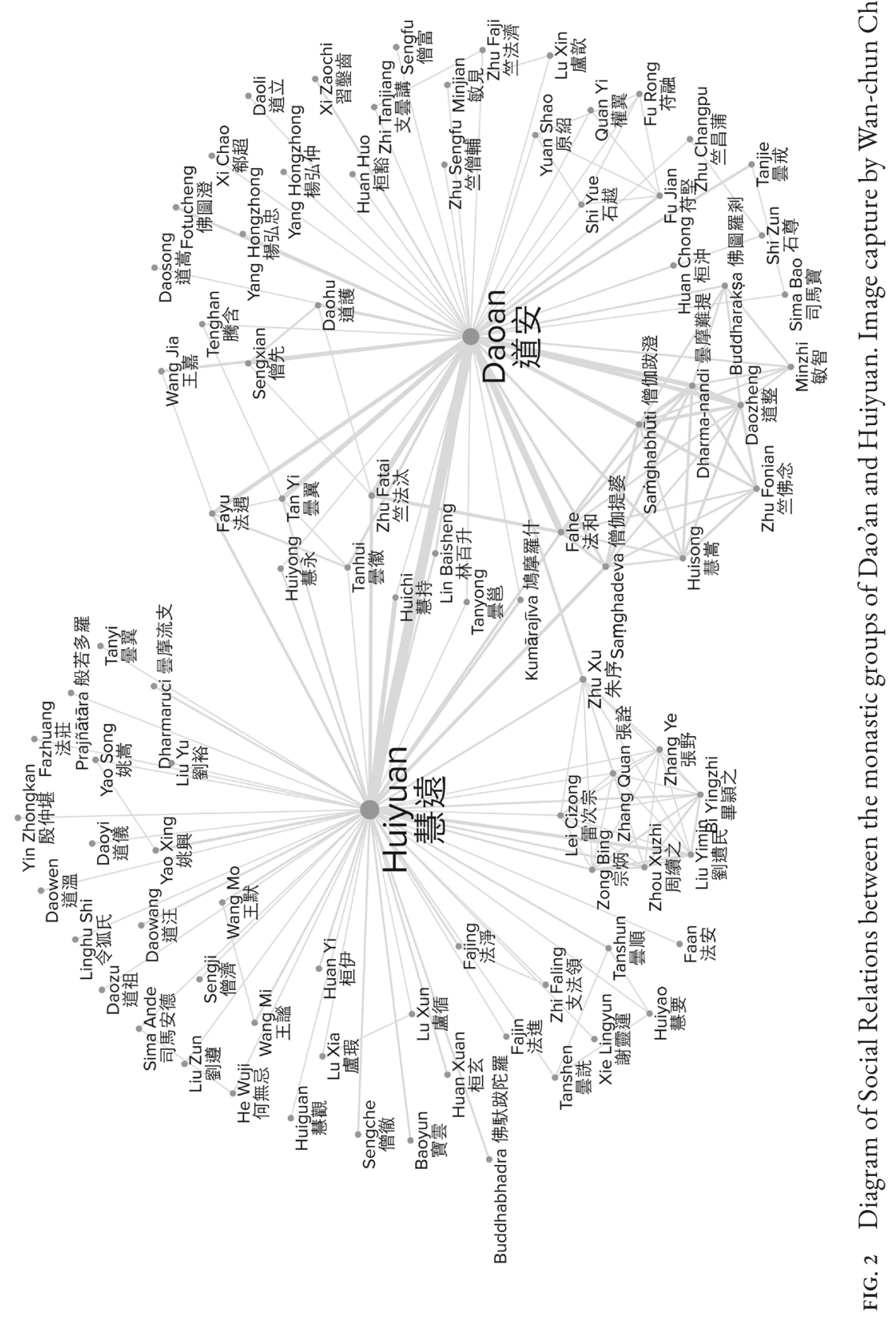


east and stopped at Kuanglu 匡盧 (i.e. Lushan). Afterwards, Huiyuan and his younger brother Huichi once again continued east and stopped at Lushan, where they finally formed the Lushan Buddhist group. Dao'an took his group of disciples to stay at Xiangyang, and they later went to Chang'an. It is especially worth noting that Tanjia and Zhuseng took the Maitreyanism faith with them to Changsha Monastery and Shangming Monastery in Jiangling.

During the Eastern Jin dynasty and Southern Dynasties, the development of Buddhism in the Jingzhou region was related to the ardent patronage it received from local bureaucrats. Research by $\mathrm{Xu}$ Zhanfei 許展飛 and Chen Changqi 陳長琦 indicates that there are written accounts of worshipping the Buddha that mention aristocratic families, including ones who had members that served as the governor of Jingzhou—such as the Wang clan of Langya 琅㑚王氏, Tao Kan 陶㑆 of Xunyang, Yu clan of Ying Chuan 穎川庆氏, Huan clan of Qiaoguo 譙國桓氏, Wang Chen of Taiyuan 太原王忱 (?-392), and Yin Zhongkan 殷仲堪 (?-399) of Chenjun 陳郡. In fact, there is existing evidence that officials from all over the Jingzhou worshipped Buddhism. ${ }^{75}$ Another clear example is that kings typically had prominent monks accompany them when they set out for garrisons. Tang Yongtong 湯用娅 pointed out, 'during the Southern Dynasties, when officials left to take up an official post in a jun (province), they often invited famous monks to come to their encampment. During the Liu Song Dynasty, this practice was even more popular'. ${ }^{76}$ It wasn't just this way during the Liu Song dynasty; later, the Northern Qi 後齊 and Liang Dynasty 梁 also carried on this practice. For example, in the Northern Qi state, when the taifu 太傅 [Grand Tutor] Xiao Ying 蕭穎 was appointed governor of Jingzhou, he asked a monk named Mingche 明徹 to come to his residence and lecture over Buddhist scriptures, and during the Liang Dynasty, a monk named Huichao 惠 超 once accompanied the Wuping hou 吳平侯 [Marquis of Wuping] Xiao Rui 蕭旵 on a tour around Xiakou 夏口. ${ }^{77}$

\footnotetext{
$75 \mathrm{Xu}$ and Chen, 'Dongjin Jingzhou Fojiao', 158.

76 Tang, Han Wei Liang Jin Nanbeichao, 452.

77 See Zhang, Hubei Lishi wenhua dili, 60; Sheng, 'San Bu sengni zhuan', 22.
} 
The earliest date when the influence of Liu Yu's inner circle entered Jingzhou that we can trace back to is 410, when Liu Yu fought Lu Xun. This event began when Liu Yu's troops were away on a campaign, which prompted Lu Xun and Xu Daofu 徐道覆 to try and take advantage of his absence by launching a direct attack on Changsha. They first defeated the troops of the governor of Jingzhou, Liu Daogui 劉道規. Xu Daofu then attacked Nankang, Luling, and Yuzhang. The governors of many prefectures abandoned their posts and fled, but He Wuji 何無忌, the governor of Jiangzhou, did not give up and fought to the death. There was also Liu Yi, the governor of Yuzhou, who was defeated at Sangluozhou. These failures shook the capital city. Liu Yu hurriedly returned with his troops, and though they were greatly outnumbered, they managed to push Lu Xun's troops back to Xunyang.

At the same time, Qiao Zong 譙縱, the prince of Xishu 西蜀, dispatched troops during internal strife in the Eastern Jin. They also asked the Later Qin to send their general, Gou Lin 苟林, along to assist with the war effort. They stationed their troops in Jiangjin, and from there launched an attack on Jiangling. Huan Qian 桓謙 was able to successfully assemble 20,000 soldiers that still supported him, which he stationed at Zhijiang (present-day Zhijiang county, Hubei Province), gravely threatening Jiangling. Within Jiangling city, disloyal sentiments brewed in many soldiers and civilians. Many communicated with Huan Qian, telling him the state of affairs within the city and serving as informants. ${ }^{78}$ Liu Yu was in dire straits, but he did receive the support of Lu Zongzhi 魯宗之, the governor of Yongzhou, who personally led troops to behead Huan Qian and also dispatched the military councillor Liu Zun 劉遵 to chase after Gou Lin. They eventually beheaded Gou Lin at Baling 巴陵 (present-day Yueyang City, Hunan Province). What is interesting is that even if Liu Daogui knew that the officials and people were partial to Huan Qian, after they emerged victorious, Liu Daoguan tracked down and destroyed

The matter is also touched on in two biographies of $X u$ Gaoseng zhuan (for Mingche 明徹 and Huichao 慧超), $T$ no. 2060, 50: 6.467.

78 Song shu 51.1473. 
all the messages sent by informers in order to pacify the public. ${ }^{79}$ This instance shows that when Liu Yu's inner circle engaged in military operations, eradicating the strength of a place and appeasing the general populace were two matters deemed of equal importance. Neither one could be overlooked.

Consequently, some in Liu Yu's inner circle condemned Huiyuan on account of the fact that he had previously been on good terms with Lu Xun. Despite this, Liu Yu was still able to differentiate between a correct action and an incorrect one, and he thus proclaimed, 'Master Huiyuan's character is of the utmost quality; he would certainly treat any person with benevolence'. Indeed, instead of admonishing Huiyuan, Liu Yu dispatched an envoy to pay respects to him by presenting money and grains as gifts. ${ }^{80}$

In 412, Liu Yu defeated Liu Yi, broke into Jiangling, and defeated the governor of Jingzhou, Sima Xiuzhi 司馬休之 (?-417). Sima Xiuzhi had zealously supported Buddhism and been strongly supported by his subjects as well. ${ }^{81}$ Consequently, in order to demonstrate he was tolerant and to settle down the people, Liu $\mathrm{Yu}$ venerated monastics even more. It was also at this time that Yuan Bao 袁豹 (?-413), a Grand Commandant (taiwei 太尉) and Administrator (zhangshi 長史), introduced Liu Yu to Buddhabhadra, whom Sima Xiuzhi had previously backed and treated deferentially. Liu Yu 'worshipped [Buddhabhadra] immensely and provided him with all manner of material goods and tribute'. He even invited Buddhabhadra to come to Daochang Monastery,

79 For a rather comprehensive narrating of the matter, see Zizhi tongjian 115.3637-38.

${ }^{80}$ Gaoseng zhuan, T no. 2059, 50: 357.

81 Gaoseng zhuan, T no. 2059, 50: 368:

After Kumārajīva died, Huiguan went to Jingzhou. At that time, Xiuzhi, the Sima in charge of military affairs in Jingzhou, revered him. He established Gaoli Monastery 高悝寺 for him. Huiguan also made half of the people in Jingzhou and Chuzhou give up their previous faith and convert to believe in Buddhism. 什亡後, (慧觀)迺南適荊州. 州將司馬休之甚相敬 重, 於彼立高悝寺, 使夫荊楚之民迴邪歸正者, 十有其半. 
where he had living accommodations arranged for him. ${ }^{82}$ In addition, Liu Yu treated Huiguan, a disciple of Buddhabhadra, 'deferentially with all his heart, just as those before had done [toward Buddhabhadra]'. ${ }^{83}$ From this, it is clear how Liu Yu ran Jingzhou, a place where Buddhist sentiments were especially strong-he regarded deferentially treating prominent monks as a first step to settling down the people.

Next is Liu Zun 劉遵 (488-535), who established Zhulin Monastery 竹林寺 in Jiangling and invited Huiyuan's disciple, Tanshun 昙順 (347-425), to come and manage the monastery's affairs. ${ }^{84}$ According to Yang Weizhong's 楊維中 research, Liu Zun and Liu Zunkao 劉遵考 are actually two different people. Yang Weizhong proved this by combing through various documents related to the founding of Zhulin Monastery. Construction on Zhulin Monastery was overseen by the Nanman xiaowei 南蠻校尉 [Military Officer of Nanman]. Yang Wei believes that this project was carried out by the person who served under this title in 410 , during the time of $\mathrm{Lu}$ Xun's rebellion一that is, Liu Zun ${ }^{85}$ (of the art name Huiming 慧明

\footnotetext{
82 Gaoseng zhuan, T no. 2059, 50: 335.

83 Gaoseng zhuan, T no. 2059, 50: 368.

84 Gaoseng zhuan, T no. 2059, 50: 363.

85 Song shu 51.1474 reads:
}

Liu Zun is the art name Huiming, who is a native of Huaxi 海西, Linhuai 臨淮. He was the uncle of Liu Daogui's maternal aunt. Liu Zun served as the right general, the neishi 内史 (minister) of Xuancheng, and governor of Huainan. In 415, Liu Zun passed away. The emperor conferred a posthumous military title upon him and also posthumously had him declared the 'Marquis of Jianli Xian, Lord of 700 families'. 遵字慧明, 臨淮海西人, 道規 從母兄蕭氏舅也. 官至右將軍、宣城內史、淮南太守. 義熙十年, 卒, 追贈撫 軍將軍. 追封監利縣侯, 食邑七百戶.

The same source also reports that when Liu Daogui was battling against the rebellion of Lu Xun, Gou Lin and Huan Qian both dispatched troops, threatening the safety of Jiangling from two fronts. Liu Daogui 'awarded Liu Xun by conferring the title of 'Military Officer of Nanman' 南蠻校尉 upon him. The military councillor Liu Zun quickly launched an attack. He attacked Huan Qian by both 
who was from Haixi of Linhuai and an uncle of Liu Daogui's 劉道 規 aunt); he believes it was certainly not Liu Zunkao, a relative of Liu Yu, who was transferred from the position of Military Officer of Nanman to governor of Yongzhou in $426 .{ }^{86}$ After the monastery's completion, everyone paid close attention to Zhulin Monastery on account of the fact that it was managed by Tanshun, especially because he was an outstanding disciple of Huiyuan of Lushan. In addition, another distinguished monk of Huiyuan's, Tanyong 尝 邑, also stayed at Zhulin Monastery for some time. Thus, it is not likely that the monastery was established after Huiyuan passed away; rather, it was likely built sometime around 410 and 412 when Liu Zun was the Military Officer of Nanman. That is to say that the most reasonable time that the monastery was built was around the time when Liu Yu's inner circle suffered the hardships of war most intensely ${ }^{87}$ and a great many of their soldiers had been injured and fallen ill. ${ }^{88}$ Although there are no records detailing why Zhulin

a water front and land front, delivering a crushing defeat' 解南蠻校尉印以授諮 議參軍劉遵. 馳往攻謙, 水陸齊進, 謙大敗. See Song shu 51.1474.

Yang Weizhong believes that beginning from this time, Liu Xun was likely appointed the Military Officer of Nanman. According to Song shu 2.28:

In the fourth month of 412, Liu Yi replaced Liu Daogui to become the governor of Jingzhou. He and Xi Sengshi of Danyang formed a strong relationship. And when Liu Yi headed west to protect Jiangling, the ministers under his command requested to go with him. At this time, Liu Yi invited Xi Sengshi to assume the position of 'Military Officer of Nanman'. 及西鎮 江陵,豫州舊府,多割以自隨, 請僧施為南蠻校尉.

It is clear that Liu Zun was the Military Officer of Nanman from $410 \mathrm{CE}$ to $412 \mathrm{CE}$, and afterwards the post was filled by Xi Sengshi 郗僧施 (?-412).

86 In the eleventh month of 426, 'Liu Zunkao, Military Officer of Nanman 南蠻校尉, shifted to governor of Yongzhou’ 以南蠻校尉劉遵考為雍州刺史. See Song shu 5.75 .

87 Yang, 'Dongjin shiqi Jingzhou Fosi kao'.

${ }^{88}$ Right after Liu Yu defeated the Southern Yan, he received an imperial edict to return to Jiankang. Many soldiers had been injured or grown sick, and the total military strength in Jiankang was no more than 1,000 men strong. Con- 
Monastery was established, it was almost certainly intended to commemorate those who had died, to be a place for prayer, and to appeal to popular sentiments in the region. This can also be regarded as an important political strategy of Liu Yu's inner circle.

During the long operation of Liu Yu's inner circle in Jingzhou, the officers placed in charge of various regions always maintained this kind of religious policy. For example, Liu Yu decreed, '[Shi Huiguan] should associate with the Xizhonglang 西中郎'. ${ }^{89}$ Here, Xizhonglang is a title that refers to Liu Yilong 劉義隆 (407-453), the son of Liu Yu. In 419, Liu Yilong was made the commanding officer of Luoyang; he was also the commanding military officer of six states (Jingzhou, Yizhou, Ningzhou, Yongzhou, Liangzhou, and Qinzhou), the head of military affairs in four provinces (Henan Jun and Guangping Jun of Yuzhou as well as Yicheng Jun and Songzi Jun of Yangzhou), Commander of the Imperial Corps (xizhong langjiang 西中郎將), and the governor of Jingzhou. ${ }^{90}$

In 423, Liu Yixuan 劉義宣 (415-454), the Prince of Qiao 譙王, went to Jingzhou to assume his post there. On the way, he requested that Gunabhadra and Huiqu come to Jingzhou with him. According to Song shu:

[Gunabhadra] founded a new monastery (Xin Monastery 辛寺) and established a new palace hall. This new monastery produced translations of numerous texts, such as Wuyou wang [jing] 無憂王 [經] [Aśoka sutra], Guoqu xianzai yinguo 過去現在因果, Wuliangshou [jing] 無量壽[經] [Amitâyus sutra], the sole juan of Nibuan [jing] 泥洹[經] [Nirvana Sutra], Yanjuemo [jing] 央掘魔[經] [Skt. Avgulimālika-sūtra], Xiangxu jietuo [di boluomi liaoyi jing] 相續解 脫地波羅蜜了義經 [Skt. Samdhinirmocana-sütra], Diyi yi wuxiang lïe 第一義五相略, Ba jixiang [jing] 八吉祥[經] [Skt. Ashtamangala], and over a hundred more. ${ }^{91}$

fronted with Lu Xun's force of over 100,000 soldiers, the disparity in strength between the two forces was great. See Song shu 1.19.

89 Gaoseng zhuan, T no. 2059, 50: 368.

90 Song shu 5.71. 
As for Huiqu, after Liu Yixuan rose up in rebellion, he disobeyed his orders and did not follow Yixuan's mission. ${ }^{92}$

There is also the instance of Sengche 僧徹, who was another disciple of Huiyuan. After Huiyuan passed away, Sengche travelled to the south and headed to Jingzhou. He first went to Wuceng Monastery, within the city of Jiangling, and later in his life he moved to Pipa Monastery in Jiangling. He also oversaw the ordination ceremony wherein Liu Yikang 劉義康 (409-451) and Xiao Sihua 蕭 思話 (402-455) took refuge in Buddhism. After Sengche died, Liu Yixuan had a tomb built for him. ${ }^{93}$ In 439, Liu Yiji 劉義季 (415447), the Prince of Hengyang 衡陽 who was in charge of Jingzhou, personally went to the room of Tanguang 是光 (407-473), a monk of Changsha Monastery, to discuss Buddhist theology with him. Liu Yiji also provided him with a carriage, attendants, and a monthly stipend of 10,000 qian 錢. ${ }^{94}$ Sengyin 僧隱 also stayed at Pipa Monastery, where he mastered chan cultivation, and as a result, the practice became popular throughout the Jingzhou region. During the Xiaojian 孝建 Period (approx. 454-456), Liu Xiuyou 劉休祐 (445-471), the Prince of Shanyang 山陽王, and his zhangshi (minister) Zhang Dai 張岱 (414-484) jointly consulted with Sengyin over precepts. During this same period, Liu Xiuruo 劉休若 (448-471), the Prince of Baling 巴陵王, and Liu Jingsu 劉景素 (452-476), the Prince of Jianping 建平王, also went to Sengyin's place of residence to pay him a visit. They treated Sengyin deferentially, kneeling in his presence. ${ }^{95}$ There are a great deal of related events-indeed, far too many to warrant mentioning them all-but for the time being, we have sufficiently looked over the political and religious situation of Jingzhou during that time.

Later in his life, Faxian left the capital city of Jiankang, choosing to spend his later years in Jingzhou. This just happened to coincide

\footnotetext{
91 Gaoseng zhuan, T no. 2059, 50: 334.

92 Gaoseng zhuan, T no. 2059, 50: 416.

93 Gaoseng zhuan, T no. 2059, 50: 370.

94 Gaoseng zhuan, T no. 2059, 50: 416.

95 Gaoseng zhuan, T no. 2059, 50: 401.
} 
with the time when Liu Yilong 劉義隆 (407-453) was appointed the highest commanding officer of Jingzhou. However, at this time Liu Yilong was only ten years old. Liu Yu was well aware that Zhang Shao 張邵 (355-429) wholeheartedly devoted himself to his work and possessed tremendous energy, so he appointed Zhang Shao as a sima 司馬 (Minister of War) and made him a minister of Nan Jun 南郡. This put Zhang Shao in a position where he was personally responsible for all strategic decisions in the region. ${ }^{6}$ Zhang Shao had been born into a family from Wu Jun that worshipped Buddhism, and he accordingly associated with many prominent, well known monks. Zhang Shao ordered his son, Zhang Fu 張敷, to accompany Shi Daowen 釋道溫 (398-466), ${ }^{97}$ a disciple of Huiyuan, and listen to his teachings. In particular, Zhang Shao revered Daoye 道業, who was proficient at Shisong lü 十誦律 (Ten Recitation over Vinaya) and chan meditation. In Gusu 姑蘇, Zhang Shao established Xianju Monastery 閑居寺 for Shi Daoye. ${ }^{98}$ The deferential treatment of prominent Buddhist monks by Liu Yilong was also likely supported by Zhang Shao. Finally, when it came to Faxian, who strictly adhered to Buddhist precepts and whose efforts to translate Buddhist texts at Daochang monastery were supported by Meng Yi and Chu Shudu of Liu Yu's inner circle, Zhang Shao also treated this eminent monk with the utmost deference.

By again performing an investigation of Faxian from the perspective of his monk associates, it seems Faxian first met Baoyun 寶 雲 (376-449) and Zhiyan 智嚴 (350-427) when he was travelling to the Indian subcontinent to collect scriptures (Fig. 3). After returning to China, Faxian had a brief, first encounter with Buddhabhadra at Lushan, who had been invited to China by Zhiyan. In Chang'an, Buddhabhadra had been largely ostracized by Kumārajīva's monastic group, and he was later expelled on account of his 'five boats' prediction. As a result, his disciples, which included over forty people, such as Baoyun and Huiguan, were dispersed. Later, Buddhabhadra and

\footnotetext{
96 Song shu 46.1394-1395.

97 Gaoseng zhuan, T no. 2059, 50: 472.

98 Gaoseng zhuan, T no. 2059, 50: 401.
} 


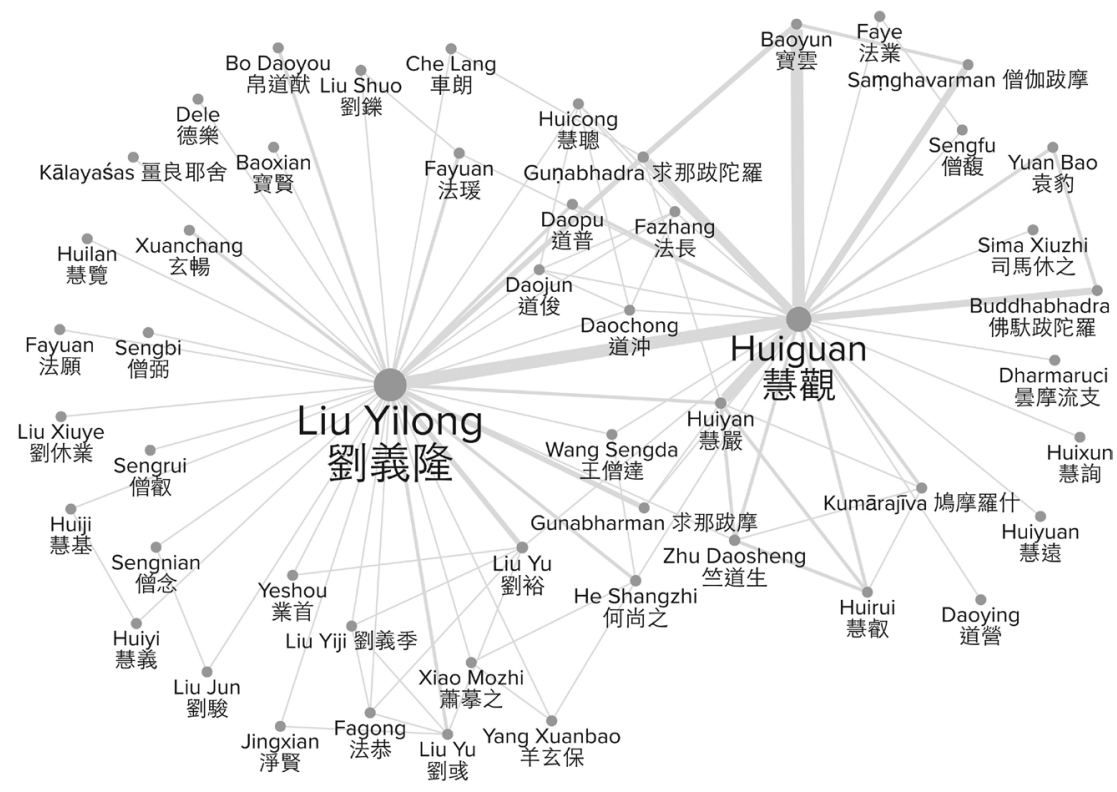

FIG. 3 Social Relations Diagram Regarding Liu Yilong and Huiguan. Image capture by Wan-chun Chiu.

Huiguan moved west to Jingzhou, and they were politely received by Sima Xiuzhi and Liu Yu. On account of the later invitation of Liu Yu, Buddhabhadra headed back to the capital city where he was reunited with Baoyun, Faxian, and even Zhiyan. There, in Jiankang, they collectively set about translating texts at Daochang Monastery. ${ }^{99}$

Afterwards, Faxian forged ties with Buddhabhadra and his disciples. This is likely related to the fact that both of them believed in Maitreya. A number of perspectives can be considered to understand why the majority of Buddhabhadra's disciples worshipped Maitreya. From the perspective of Buddhist ideology, we can surmise that Maitreya was worshipped by both Mahayana and Hinayana Buddhism. From a scriptural perspective, Maitreya teachings can be found in the 'Learning of Prajñā (pāramitāe)' 般 若學 and texts from the Sarvastivada and Yogacara schools. From the perspective of practice, Buddhabhadra 'became famous when

99 Gaoseng zhuan, T no. 2059, 50: 335. 
he was young from practicing chan and keeping precepts'. Indeed, Buddhabhadra meditated everyday according to chan practices and strictly kept to Buddhist precepts. He even once 'briefly reached Tusita, where he paid respects to the Maitreya Buddha' ${ }^{100}$ Buddhabhadra was truly different from the Kumārajīva in Chang'an, because he did more than just translate scriptures-he also practiced Dharma.

In the case of Baoyun, besides 'following Buddhabhadra and cultivating the chan path', he also believed in Maitreyanism. Meisō den $s h \bar{o}$ 名僧傳抄 [Biographies of Famous Monks] records:

beneath a statue of the Maitreya Buddha, Baoyun repented for fifty days. One night he saw the Maitreya Buddha statue emit miraculous rays of light that were as bright as the sky at midday. People gathered on the streets to watch the curious sight. Many prominent monks who had cultivated themselves well are also said to have seen the statue emit such a light.

Such lines as 'people gathered on the streets to watch' and 'many prominent monks who had cultivated themselves well are also said to have seen the statue emit such a light ${ }^{\prime 101}$ clarify importance, and from this passage it becomes clear just how devout Baoyun's faith in Maitreyanism was.

It is even more worth noting that, from this, we can see that worship and repenting are important gates to enlightenment in Maitreyanism. As for Zhiyan:

After he accepted the five precepts, he violated them to some extent. Later, he formally joined the Sangha and accepted the complete precepts. But on account of his previous behaviour, he often doubted that he truly received the essence of precepts. As a result, he was deeply frightened. So, he spent many years cultivating chan. Zhiyan was still unable to get an answer via his own efforts alone,

${ }^{100}$ Gaoseng zhuan, T no. 2059, 50: 334.

101 Mingseng zhuan, X no. 1523, 77: 358. 
and he even crossed the ocean to go to India, seeking an answer to this question from preeminent monks. When he encountered a prominent monk that had already become an Arhat, he also asked this question. The Arhat did not dare to lightly answer Zhiyan, so he entered Tusita and asked Maitreya this question. Maitreya told him that Zhiyan had grasped the essence of precepts.

嘗受五戒有所雐犯, 後入道受具足, 常疑不得戒, 每以為懼. 積年禪 觀而不能自了, 遂更汎海, 重到天笂, 諮諸明達. 值羅漢比丘, 具以 事問羅漢. 羅漢不敢判決, 乃為嚴入定, 往泉率宮諮彌勒, 彌勒答稱 得戒. ${ }^{102}$

In other words, one's understanding of Buddhist scriptures and whether or not they have received precepts is not important, for monks are able to cultivate themselves in a way that produces a meditative state wherein they can enter Tusita. However, the ultimate objective of this is still being reborn in the Pure Land. That is to say that one would want to be reborn in the 'Tuṣita Pure Land', encounter Maitreya, and be taught Dharma. Otherwise, they would want to be reborn into the human realm when Maitreya is also reborn into this realm, and then they can help Maitreya establish a Pure Land in the human realm after he holds the three assemblies under the Longhua Tree. Ultimately, the most important belief held by believers in Maitreya was belief in Maitreyanism itself. Among monastic believers in Maitreyanism, holding fast to all the precepts was deemed necessary; among lay believers, taking up the five precepts or the eight precepts pledge was considered mandatory.

It is thus evident that Buddhabhadra, Zhiyan, Baoyun, and Faxian were not connected to each other simply because they passed through Chang'an and the monastic group of Huiyuan, for they also attached importance to chan meditation 禪觀 and mutually promoted Maitreyanism. Indeed, they were all on very close terms and collaborated to advance a shared ideology. That said, in 418 Daochang Monastery changed the focus of its translation efforts to focus on the

102 Gaoseng zhuan, T no. 2059, 50: 339. 
Huayan jing 華嚴經 (Flower Garland Sutra; Skt. Avatamsaka-sūtra), and it never translated Vinaya scriptures again. As a result, Faxian returned to Xin Monastery in Jingzhou, hoping to find new opportunities to translate Vinaya scriptures. These events are likely related to Buddhabhadra's history in Jiangling and his relationship with Liu Yu's inner circle, which sponsored Buddhist activities in Jingzhou. In the end, an elderly Faxian left the Buddhist circles of Jiankang that advocated for the Free School, took the recommendation of Huiguan, ${ }^{103}$ and went to Jingzhou, where chan meditation and Vinaya was valued.

\section{Conclusions}

During the war-riddled period of the Eastern Jin and Sixteen Kingdoms, chaos forced people to relocate and scatter, but this chaos also served another function-it consolidated certain communities, and over this period of time Buddhism developed in a way that was only natural. Firstly, monastic groups formed around Dao'an, Kumārajīva, and Huiyuan during this time. Monks that had been dispersed across China were able to take refuge in these groups, which allowed them a means to live, spread Dharma, and practice Buddhism. Secondly, there were also some monks of virtuous conduct and high reputation that were able to convert these qualities into winning the support of major benefactors. However, given that the power dynamics were constantly changing during this period, it became essential for prom-

103 At that time, the Buddhist ideology that became popular among the royal family, nobility, and scholarly officials in the capital was Kongzong 空宗 [Void Sect], which combined xuanxue 玄學 [Dark Learning] ideas with such Buddhist works as the Prajñā Sutra 般若經 and the Vimalakirti Sutra 維摩經. The next most popular Buddhist ideology was Youzong 有宗 [Existence Sect], which combined the Confucian notion of harmony with Buddhist notions of karma, Buddha nature, and the Dharma body. Tang Yongtong (Han Wei Liangjin, 297) called it the 'Southern rule of Buddhism' (佛教之南統). For Du Jiwen's 杜繼文 explanation of 'Mingshi Fojiao'名士佛教, see Du, Fojiao shi, 154-55. 
inent monks of this period to maintain equidistant relations with new and old powers alike. This paper analysed the intertwined web of social relationships between monastic circles and benefactors that Faxian forged after returning from abroad to disseminate the Buddhist texts he acquired from foreign lands, a process which happened around the time of the emergence of Liu Yu's political force. Such analysis clearly portrays the development of Buddhist history at the time while also providing additional perspectives that magnify the contributions of Faxian.

Liu Yu's inner circle emerged suddenly on the battlefields during the final years of the Eastern Jin. Liu Yu was situated at the head of his inner circle, and he placed great emphasis on recording meritorious deeds performed by outstanding men, grieving over those that perished, and providing for their surviving families. When it came to handling those who died prematurely, Buddhism presented a far better approach than that which was offered by the rationalistic Confucianism. Although there are very few instances of Buddhists making offerings to the dead that are recorded before the Tang dynasty, such examples as Sengdao holding ceremonies and burning incenses to commemorate the deceased in Northern Wei prove that the activities during the Liu Song were not isolated activities. In addition, over the course of progressively recapturing such areas as Xuzhou, Haizhou, and Jingzhou, Liu Yu respected and accorded with local Buddhist beliefs. Not only did he protect existing monasteries, such as Qiji Monastery, but he also founded new ones, like Zhulin Monastery and Longhua Monastery. More importantly, he provided refuge to those displaced by the turmoil in the North and asylum to those fleeing campaigns to exterminate Buddhism. His contribution to safeguarding Buddhism cannot be overlooked.

When Liu Yu and his inner circle seized control of Jiangzuo, it was plunged into the upper echelons of society. Questions regarding how to receive eminent monks, how to appropriately perform Buddhist rituals, how to hold Dharma assemblies, and even how to found temples, build pagodas, and translate Buddhist texts all became matters that Liu Yu's inner circle immediately needed answers to. Receiving eminent monks from distant lands indeed seems an optimal shortcut 
for entering into Buddhist circles. At the onset of Liu Yu's political aspirations, Yuan Bao was completely oblivious of Buddhabhadra's status. Later, Liu Daolian received Faxian in a manner both deferential and regal, and he also supported Faxian when he established Longhua Monastery and propagated Maitreya Buddha. We can look even further ahead to when Meng Yi and Chu Shudu helped with the project of translating Buddhist texts at Daochang Monastery. Looking over such progress, it is clear that Liu Yu's understanding of Buddhist affairs and self-cultivation improved immensely with time, and this engendered the tremendous opportunities and fortunate tidings that presented themselves to Buddhism during this time.

After Faxian returned to China, he developed a multi-layered web of tightly knit relationships. His journey to the West acquainted him with Bao Yun and Zhi Yan, ${ }^{104}$ who connected him with Huiguan (who had headed north to Chang'an after being in the monastic groups of Dao'an and Huiyuan) and Buddhabhadra, providing Faxian with the opportunity to translate Buddhist scripture and vinaya. The analysis in this present text shows that Longhua Monastery was built according to the Longhua Image provided by Faxian and that this led to the propagation of Rebirth Maitreyanism. This influenced Maitreyanism in southern China and afterwards led to a series of related texts, such as Fu Liang's Mile zan [Praising Maitreya], emerging in the Jiangzuo region. These events also led to the name 'Longhua' becoming widely popular. For example, there is Song Mingdi's Longhua Fayuan Wen 龍華法願文 [Text on Longhua Dharma Wishes] and Xiao Ziliang's Longhua bui ji 龍華會記 [Records of the Longhua Assembly]; the inspiration behind such works can be traced back to Faxian's Longhua Image. In addition, Faxian also urgently sought to translate monastic precepts (Vinaya), and he attached great importance to chan cultivation and precepts, which is actually intimately related to Maitreyanism. Such an opinion was not limited to Faxian, though, for it was also the collective, great ambition of Chinese and foreign Buddhist monks in China during the Eastern Jin and Sixteen Kingdoms period.

\footnotetext{
104 Wang, 'Faxian yu Mile Xinyang', 176.
} 


\section{Appendix One}

\section{Social Relations Between Faxian 法顯 and Meng Yi 孟顗}

From Fig. 2, we can realize a few things: First, Faxian and Meng Yi were brought together by Buddhabhadra to translate Buddhist works in a group. Among them, Chu Shudu 褚叔度 and Meng Yi were both benefactors of the translations carried out at Daochang Monastery. Other related monks include Huiyan 慧嚴, Huiyi 慧義, and Faye 法業. Second, Meng Yi was at the centre of this. In addition to establishing pagodas and monasteries, he had also graciously received prominent Buddhist figures such as the Marquis of Anyang (Anyang hou 安陽侯) Juqu Jingsheng 沮渠京聲 (369-464), Dharmamitra 曇 摩密多 (356-422), Kalamyasas 畺良耶舍 (383-442), Chaojin 超進 (380-475?), Huilan 慧覽 (d.u.), Hongming 弘明 (403-486), Sengyi 僧翼, Miaoyin 妙音 (d.u.), and Huiqiong 慧瓊 (d.u.).

As for the web centred around Faxian, he一along with Huiwei 慧 嵬 (d.u.), Huijing 慧景 (?-403), Daozheng 道整 (d.u.), and Huiying 慧應 (?-402) - make up the group of figures that travelled west to obtain scriptures. Throughout this process, the spirit of Mahākāśyapa miraculously appeared before Faxian while he was praying at Vulture Peak during his journeys. The next matter touches on when Faxian became sick in a foreign land and greatly missed the food of his home. As a result, the person supporting him there had a sage use a miraculous ability to go to Pengcheng-the home of Faxian. There, the sage went to the home of Wu Cangying to receive an offering of food, but the family's dog bit the sage. After Wu Cangying learned about this, he was struck with an immense sense of guilt, and thus had his home converted into a monastery. He also had a statue of the Buddha made to be placed in this monastery. As for Luo Yuejia 羅閱 家, this refers to Zhimeng 智猛 (d.u.) who was encourage by Faxian to head to Pataliputra, a place in the Indian subcontinent, where he came across Brahmins. There, Zhimeng received a text of the Sanskrit edition of the Da bannipan jing 大般泥洹經 (Skt. Mahāparinirvāna Sütra). Additionally, Li Yi was the first official to receive and support Faxian after he returned from abroad. 


\section{Appendix Two}

\section{Records of Maitreyanism Believers}

\begin{tabular}{|c|c|c|}
\hline Record & Translation & Sūtra passage \\
\hline $\begin{array}{l}\text { Gaoseng zhuan, } \\
\text { T no. 2059, 50: } \\
352\end{array}$ & $\begin{array}{l}\text { Fu Jian 苻堅 (338-385) dispatched envoys to } \\
\text { present Dao'an with gifts, which included a } \\
\text { foreign produced seated-Buddha image covered } \\
\text { in gold leaves along with a seated-Buddha image } \\
\text { made of gold, a Maitreya image adorned with } \\
\text { pearls, a Buddha image made of embroidered } \\
\text { gold, a Buddha image made of silk, and a } \\
\text { weaving turned into an image, and every time a } \\
\text { Dharma assembly was held and everyone came } \\
\text { together, these images were brought together to } \\
\text { be worshipped. }\end{array}$ & $\begin{array}{l}\text { 符堅遣使, 送外國, } \\
\text { 金薄倚像高七尺, } \\
\text { 又金坐像、結珠爾 } \\
\text { 勒像、金縷繡像、 } \\
\text { 織成像各一張, 每 } \\
\text { 講會法聚, 輯羅 } \\
\text { 尊像. }\end{array}$ \\
\hline
\end{tabular}

Gaoseng zhuan, Dao'an and his disciples such as Fayu always T no. 2059, 50: worshipped Dharma, in front of Maitreya 352 he made pledges that they were willing to be

安每與弟子法遇 等, 於彌勒前立誓 願生皕率. reincarnated in Tuṣita in his next life.

On Dai Yong, Fayuan zbulin, T no. 2122, 53: 16.406
Dai Kui's 戴迬 (331?-396) second son was Dai Yong 戴顒 (377-441) of the art name Zhong Ruo 仲若.... When Jiang Yi 江夷 (384-431) of Jiyang was young, he was friends with Dai Yong. Jiang Yi once commissioned Dai Yong to make a Guanyin Bodhisattva statue for him. Dai Yong racked his brain trying to produce a consummate statue, but after several years of work he still had not produced a work that he deemed to be of a consummate 'physical appearance'. Later, while Dai Yong was dreaming, he encountered a person that told him that no connection existed between Jiang Yi and Guanyin, but that he could transform the statue into one of Maitreya. Dai Yong then immediately stopped his work and sent a letter to Jiang Yi, telling him about this dream. Before he had sent off the letter, Dai Yong received a letter from Jiang Yi, detailing an identical dream. Dai Yong was extremely happy with this turn of events, figuring it was a response from deities. He then changed the statue into one of Maitreya. The sculpting process then went extremely smoothly. Hardly having to think about his work at all, he was able to produce a consummate statue of Maitreya.
迳弟二子颙字仲 若, .......濟陽江夷 少與顆友, 夷嘗託 颙造觀世音像, 致 力馨思欲令盡美, 而相好不圓積年 無成. 後夢有人告 之日: “江夷於觀 世音無緣, 可改為 彌勒菩薩.'戴即 停手馳書報江, 信 未及發而江書已 至, 俱於此夕感 夢, 語事符同. 戴 喜於神應即改為 彌勒, 於是觸手成 妙, 初不稽思, 光 顏圓滿俄爾而成. 有識讚仰咸悟因 緣之匪差, 此像舊 在會稽龍華寺. 


\begin{tabular}{|c|c|c|}
\hline Record & Translation & Sūtra passage \\
\hline $\begin{array}{l}\text { On Faxiang, } \\
\text { Meisō den shō, } \\
28.359\end{array}$ & $\begin{array}{l}\text { Faxiang was extremely diligent in his cultivation } \\
\text { and had strong ideals as well. In the ninth year } \\
\text { of Yuanjia (432), he established the Maitreya } \\
\text { Vihara. }\end{array}$ & $\begin{array}{l}\text { 精進有志節, 以元 } \\
\text { 嘉九年, 立彌勒 } \\
\text { 精舍. }\end{array}$ \\
\hline $\begin{array}{l}\text { On Fasheng, } \\
\text { Meisō den shō, } \\
27.359\end{array}$ & $\begin{array}{l}\text { Fasheng and his masters and friends, numbering } \\
\text { twenty-nine in total, travelled to the far away } \\
\text { Indian subcontinent together... They saw } \\
\text { candana wood that had been turned into a } \\
\text { Maitreya statue. It was eight } x u n \text { tall. One } x u n \\
\text { is equivalent to one Chinese } \text { zhang. } 480 \text { years } \\
\text { after the Buddha attained nirvana, there was an } \\
\text { Arhat named Kalinanda 可利難陀 who aspired } \\
\text { to enlighten people. In Tusiita, he saw Maitreya, } \\
\text { and afterwards he painted the appearance } \\
\text { of Maitreya according to what he had seen. } \\
\text { Kalinanda also carved a Buddha statue according } \\
\text { to this. }\end{array}$ & $\begin{array}{l}\text { (法盛) 率師友, } \\
\text { 與二十九人遠詣 } \\
\text { 天笂........見牛頭 } \\
\text { 梅檀彌勒像, 身高 } \\
\text { 八尋, 一尋是此國 } \\
\text { 一丈也, 佛滅度後 } \\
\text { 四百八十年中, 有 } \\
\text { 羅漢名可利難陀, } \\
\text { 為濟人故, 外貿率 } \\
\text { 天, 寫佛真形, 印 } \\
\text { 此像也. }\end{array}$ \\
\hline $\begin{array}{l}\text { On Tanfu, } \\
\text { Meisō den shō, } \\
27.359\end{array}$ & $\begin{array}{l}\text { Tanfu used his wealth to make copies of the } \\
\text { Lotus Sutra, Longer Sukhāvativyūha Sütra, } \\
\text { Maitreya Sutra, Sitianwang jing 四天王經 } \\
\text { [Sutra of Four Heavenly Kings], Yijiao Sutra } \\
\text { 遺教經 [Sutra of Bequeathed Teachings], } \\
\text { Xianjie Qianfo ming jing 賢劫千佛名經 [Sutra } \\
\text { of the Names of the Thousand Buddhas of } \\
\text { the Bhadrakalpa], and Sengni jieben 僧尼戒本 } \\
\text { [Disciplines of Monks and Nuns]. He had one } \\
\text { thousand copies of each made, and he also had } \\
\text { ten thousand wooden prayer sticks made for } \\
\text { Upavasatha. Tanfu exhausted all his assets on this } \\
\text { project, but the fruits of this work spread far. It } \\
\text { even spread to foreign countries, disseminating } \\
\text { the Buddhist doctrine far and wide. Tanfu } \\
\text { diligently cultivated himself, devoid of any } \\
\text { laziness. Someone said to him, if everything is } \\
\text { done well, then he can make it to Tușita without } \\
\text { a problem. Later, Tanfu dreamed that Maitreya } \\
\text { touched the crown of his head. There were } \\
\text { fantastic aromas in his dream and spirit dragons } \\
\text { also appeared. Over the next two years, such } \\
\text { miraculous responses appeared repeatedly. }\end{array}$ & 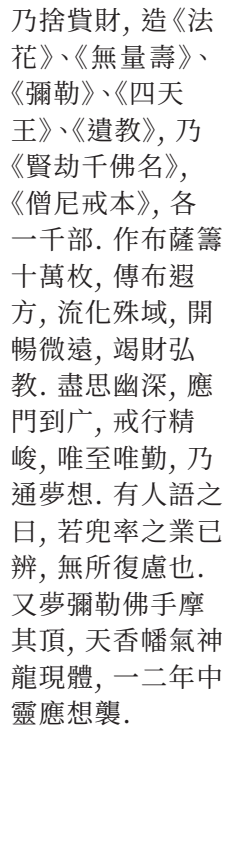 \\
\hline
\end{tabular}




\section{Bibliography}

Abbreviations

T Taishōshinshū daizōkyō大正新脩大蔵経. See Bibliography, Secondary Sources, Takakusu and Watanabe, eds. X Wanzi Xuzang jing 叉字續藏經. See Bibliography, Secondary Sources, Wanzi Xuzang jing.

\section{Primary Sources}

Chu sanzang ji ji 出三藏記集 [Collection of the documents Related to the Translation of the Tripitaka]. 15 juan. Initially compiled by Sengyou 僧祐 (445-518) in 515. T no. 2145, vol. 55.

Gaoseng Faxian zhaun 高僧法顯傳 [Account by the Eminent Monk Faxian]. 1 juan. By Faxian 法顯 (d. 418-428). T no. 2145, vol. 51. References are also made to Zhang (annot.).

Gaoseng zhuan 高僧傳 [Eminent Monk Biographies]. 14 juan. Initially completed by Huijiao 慧恔 [497-554] sometime between 519 and 522 (final version probably completed ca. 530). T no. 2059, vol. 50 .

Jin shu 晉書 [History of the Jin Dynasty]. 130 juan. By Fang Xuanling 房玄齡 (578-648) in 648. Taipei: Dingwen shuju 鼎文 書局, 1980.

Mingseng zhuan 名僧傳 [Biographies of Famous Monks]. 30 juan.

By Baochang 寶唱 (464-514+) between 510 and 514. Excerpts collected as Meisō den shō 名僧傳抄, X no. 1523, vol. 77.

Nansh $i$ 南史 [History of the Southern Dynasties]. 80 juan. By Li

Yanshou 李延壽 (fl. 650) in 659. Taipei: Dingwen shuju 鼎文書 局, 1981.

Quan Shanggu sandai Qin Han Sanguo Liuchao wen 全上古三代秦 漢三國六朝文 [Complete Texts from the Three Distant Early Dynasties, Qin, Han, Three Kingdoms, and Six Dynasties]. 746 juan. By Yan Kejun 嚴可均 (1762-1843) between 1808-1836.

Beijing: Zhonghua Shuju 中華書局, 1991.

Song shu 宋書 [History of Song of the Southern Dynasties]. 100 juan. By Shen Yue 沈約 (414-513) between 487-488. Beijing: 
Zhonghua shuju 中華書局, 1974.

Wei shu 魏書 [History of Wei of the Northern Dynasties]. 114 juan.

By Wei Shou 魏收 (506-572) between 551-554 (revised in 572).

Taipei: Dingwen shuju 鼎文書局, 1980.

Xu Gaoseng zhuan 續高僧傳 [Continuation Eminent Monk

Biography]. 30 juan. By Daoyuan 道宣 (596-667) initially in 645. T no. 2060, vol. 50.

Zengyi Ahanjing 增壹阿含經 [Skt. Ekottara-ägama]. 51 juan. Trans.

Gautama Sanghadeva (Qutan Sengqietipo 矍昙僧伽提婆; d.u.) in 398. T no. 125, vol. 2.

Zhong Ahanjing 中阿含經 [Skt. Madhyamagama].60 juan. Trans.

Gautama Sanghadeva (Qutan Sengqietipo 翟曇僧伽提婆; d.u.)

between 397-398. T no. 26, vol. 1.

Zizhi tongjian 資治通鑑 [Comprehensive mirror to aid in

government]. 294 juan. By Sima Guang 司馬光 (1019-1086?), et al., and presented to the court in 1084. Beijing: Guji chubanshe 古籍出版社, 1956.

\section{Secondary Sources}

Chen Jinhua 陳金華. ‘Faxian Deng Lufeng Hui Huiyuan Kao’ 法顯 登盧峰會慧遠考 [Research on Faxian and Huiyuan’s Encounter at Lu Peak]. Presented to the Faxian Guoji Yantaohui 法顯國際研 討會 [International Faxian Research Forum]. Shanxi: Wutaishan Dongfang Fojiao Wenhua Yanjiuyuan 五臺山東方佛教文化國際 研究院 [Mount Wutai Research Institute for Eastern Culture of Buddhism], March 2017.

Dharma Drum Institute of Liberal Arts 法鼓山佛教學院. 'Visualizing and Querying Chinese Buddhist Biographies’ 佛教傳記文學 platform. http://buddhistinformatics.ddbc.edu.tw/biographies/ socialnetworks/interface/.

Dong Zhiqiao 董志趐, ed. Guanshiyin yingyan ji sanzhong 觀世音應 驗記三種 [Three Kinds of Records on Numinous Manifestations of the Bodhisattva Avalokiteśvara]. Nanjing: Jiangsu guji chubanshe 江蘇古籍出版社, 2004.

$\mathrm{Du}$ Jiwen 杜繼文. Fojiao Shi 佛教史 [History of Buddhism]. Nanjing: Jiangsu renmin chubanshe 江蘇人民出版社, 2008. 
Fu Liang 傅亮. ‘Guanshiyin yingyan ji xu’《觀世音應驗記》序 [Forward to Numinous Manifestations of the Bodhisattva Avalokiteśvara]. In Guanshiyin yingyan ji sanzhong 觀世音應驗 記三種 [Three Kinds of Records on Numinous Manifestations of the Bodhisattva Avalokiteśvara], edited by Dong Zhiqiao 董志 䞨. Nanjing: Jiangsu guji chubanshe 江蘇古籍出版社, 2004.

Kimura Eiichi 木村英一, ed. Eon kenky $\bar{u}$ 慧遠研究 [Research on Huiyuan]. 2 vols. Tokyo: Sobunsha 創文社, 1960.

Lin Boqian 林伯謙. “'Hong Ming Ji Xi Taishan Wen” Kao Lun’ 《弘明集・檄太山文》考論 [Research on 'Hong Ming Works:

Letter to Mount Tai']. Shida xuebao: Yuyan yu Wenxue Lei 師大 學報: 語言與文學類 [Normal University Journal: Language and Literature] 60, no. 1 (2015): 59-94.

Lin Feifei 林飛飛. 'Liusong diwang yu zongjiao guanxi yanjiu' 劉宋 帝王與宗教關係研究 [Research on Relationship between Liu Song Dynasty Rulers and Religion]. Ph.D. dissertation, Nankai University 南開大學, 2013.

Liu Yuanru (Liu Yuan-ju) 劉苑如. 'Gushi de Zaisheng-Faxian cong qiufa dao chuanfa de zhuanji xushu yanjiu' 故事的再生——法 顯從求法到傳法的傳記敘述研究 [Rebirth of a Story: Research on Biographical Narration Regarding How Faxian Went from Search for Dharma to Spreading It]. In Tao zhi yan: Jingdu taobui yu Hanxue xinquan 桃之宴: 京都桃會與漢學新詮 [Peach Feast: New Explanation of the Kyoto Peach Feast and Sinology], compiled by Liu Yanru 劉苑如, 231-59. Taipei: Xinwenfeng chuban gongsi 新文豐出版公司, 2014.

_- _. 'Sanling juanshu: Liu Yu xizheng de shen sheng dijing shuxie yu jiedu’ 三靈眷屬: 劉裕西征的神、聖地景書寫與解讀 [Three Family Members: Writings and Interpretations of Spirits and Sacred Lands by Liu Yu during his Expeditions to the West]. In Lüyou wenxue yu dijing shuxie 旅遊文學與地景書寫 [Travel Literature and Landscape Descriptions], compiled by Liu Shiji 劉 石吉, Yang Yahui 楊雅惠, Zhang Jinzhong 張錦忠, Wang Yijun 王 儀君, 29-70. Kaohsiung: Sun Yat-Sen University Press 中山大學 出版社, 2013

- — - 'Sheyan yu guifan: Faxian qiufa de xinglü xushu’涉遠與歸 返: 法顯求法的行旅敘述 [Returning Home from Afar: Account 
of Faxian's Path Travelled While Seeking Dharma]. In Liu Yuan-ju's work Chaoxiang shenghuo shijie de wenxue quanshiLiuchao zongjiao xushu de shenti shijian yu kongjian shuxie 朝 向生活世界的文學詮釋——六朝宗教敘述的身體實踐與空間 書寫 [The Court's Literary Interpretation of Life: Religious Accounts of Personal Practices in Writing Spaces during the Six Dynasties]. Taipei 臺北: Xinwenfeng chuban gongsi 新文豐出版 公司, 2010.

Miyagawa Hisayuki 宮川尚志. Rikuchō-shi kenkyū: Shūkyō hen 六朝 史研究 · 宗教篇 [A Historical Study of the Six Dynasties Period: Religious History]. Kyoto: Heirakuji shoten 平樂寺書店, 1997. Nakano Tatsue 中野達慧, et al., comps. Dai Nibon zoku zōkyō大日 本續藏經 [Extended Buddhist Canon of Great Japan], 120 cases. Kyoto: Zōkyō shoin 藏經書院, 1905-1912.

Rao Zongyi 饒宗匵. ‘Zaoqi Qingzhou cheng yu Fojiao de yinyuan’ 早 期青州城與佛教的因缘 [Early Connections Between Qingzhou City and Buddhism]. Zhongguo shi yanjiu 中國史研究 [Journal of Chinese Historical Studies] 3 (2001): 49-53.

Ren Jiyu 任繼愈. Zhongguo Fojiao shi 中國佛教史 [History of Chinese Buddhism]. Beijing: Zhongguo shehui kexue chubanshe 中國社會科學出版社, 1988.

Sang Qin 桑欽. Shuijing zhu shu 水經注疏 [Commentary of

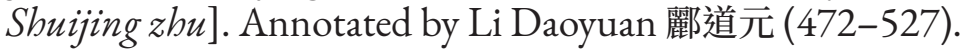
Commented on by Yang Shoujing 楊守敬 and Xiong Huizhen 熊會貞. Checked and punctuated by Duan Xizhong 段熙仲. Repunctuated by Chen Qiaoyi 陳橋驛. Nanjing: Jiangsu guji chubanshe 江蘇古籍出版社, 1989.

Sheng Hui 盛惠. 'Sanbu sengni zhuan suojian Dongjin Nanchao Fojiao chuanbo ji fenbu’ 三部僧尼傳所見東晉南朝佛教傳播及 分佈 [References from Three Biographies of Monks and Nuns About Dissemination and Distribution of Buddhism During Eastern Jin and Southern Dynasties]. Nanjing Xiaozbuang Xueyuan Xuebao 南京曉莊學院學報 [Nanjing Xiaozhuang Academy Report] 2 (March 2013): 20-25.

Song Zhiying 宋智英, comp. Song Yuan Fangzhi congkan 宋元方志 叢刊 [Collection of Local Chronicles from Song and Yuan]. 10 vols. Beijing: Zhonghua Shuju 中華書局, 1990. 
Su Bai 宿白. Zhongguo shiku si yanjiu 中國石窟寺研究 [Research on Grotto Monasteries in China]. Beijing: Wenwu chubanshe 文物 出版社, 1996.

Takakusu Junjirō 高楠順次郎, and Watanabe Kaigyoku 渡邊海旭, eds. Taishō shinshū daizōkyō 大正新修大藏經 [Buddhist Canon Compiled during the Taishō Era (1912-1926)]. 100 vols. Tokyo: Taishō issaikyō kankōkai 大正一切經刊刻會, 1924-1932.

Tang Yongtong 湯用粀. Han Wei Liangjin Nanbeichao Fojiao shi 漢魏兩晉南北朝佛教史 [Buddhist History of the Han, Wei, Eastern and Western Jin, and Northern and Southern Dynasties]. Shanghai: Shanghai shudian 上海書店, 1991.

Tian Yuqing 田餘慶. Qin Han Weijin shi tanwei 秦漢魏晉史探微 [Detailed Investigation of the Qin, Han, Wei, and Jin Dynasties]. Beijing: Zhonghua Shuju 中華書局, 2004.

Wanzi Xuzang jing 叉字續藏經 [Man Extended Buddhist Canon]. 150 vols. Xin wenfeng chuban gongsi 新文豐出版公司, Taipei 臺 北, 1968-1970. Reprint of Nakano, et al., comps., Dai Nihon $z o k u z o \bar{k} y \bar{o}$ 大日本續藏經.

Wang Rui 王芯. Wei Jin Nanbei chao Qing Xu Yan diyu zhengju yanjiu 魏晉南北朝青徐六地域政局研究 [Research on the Political Situation in Qingzhou, Xuzhou, and Yanzhou during the Wei, Jin and Northern and Southern Dynasties]. Ji'nan: Qilu shushe 齊魯書社, 2008.

Wang Xuemei 王雪梅. ‘Faxian yu Mile xinyang' 法顯與彌勒信仰 [Faxian and Maitreyanism]. Lanzhou xuekan 蘭州學刊 [Lanzhou Scholarly Periodical] 7 (2011): 173-77.

- - - Mile Xinyang Yanjiu 彌勒信仰研究 [Research of Maitreyanism]. Shanghai: Shanghai guji chubanshe 上海古籍出 版社, 2016.

Wang Yongping 王永平. 'Liu Yu yu Fojiao gaoseng zhi jiaowang jiqi dui Fofa zhi jiangyi' 劉裕與佛教高僧之交往及其對佛法之獎挹 [Liu Yu's Relationships with Prominent Buddhist Monks and his Methods of Rewarding and Promoting Dharma]. Nanjing Xiaozhuang Xueyuan Xuebao 南京曉莊學院學報 [Nanjing Xiaozhuang Academy Scholarly Journal] 1 (January 2008): 47-50. Wen Yucheng 溫玉成. 'Qingzhou Fojiao zaoxiang kaocha ji' 青州佛 教造像考察記 [Recount of Research on Production of Buddhist 
Statues in Qingzhou]. Accessed June 30, 2017. https://www. douban.com/group/topic/8207338/.

Xia Yihui 夏毅輝. 'Buyi Guozhu ze fashi nan li zhiyi’「不依國主, 則 法事難立」質疑 [Calling into Question 'Without Relying on Emperors Buddhist Rituals are Hard to Hold']. Qiusuo 求索 [Quest] 1 (2003): 215-17.

Xia Zengmin 夏增民. 'Ruxue chuanbo yu Han Wei Liuchao wenhua bianqian’ 儒學傳播與漢魏六朝文化變遷 [The Dissemination of Buddhism and Cultural Changes throughout the Han, Wei, and Six Dynasties]. Ph.D. dissertation, Fudan University 復旦大學, 2007.

Xin Jing 心淨. 'Guanyu Liang Huang Bao Chan’關於「梁皇寶懺」 [Regarding 'the Emperor Liang Repentance']. Fojiao wenhua 佛 教文化 [Buddhist Culture] 3 (2003): 53-55.

Xu Zhanfei 許展飛, Chen Zhangqi 陳長琦. 'Dongjin Jingzhou Fojiao jueqi yuanyin kao’ 東晉荊州佛教崛起原因考 [Exploration of Reasons Leading to the Emergence of Buddhism in Jingzhou during the Eastern Jin]. Xueshu yanjiu 學術研究 [Scholarly Research] 4 (2008): 157-58.

Yan Gengwang 嚴耕望. Wei Jin Nanbeichao Fojiao dili gao 魏晉 南北朝佛教地理稿 [Geography of Buddhism in Wei, Jin, and Northern and Southern Dynasties]. Shanghai: Shanghai guji chubanshe 上海古籍出版社, 2007.

Yang Huinan 楊惠南. 'Hanyi Fojing zhong de Mile xinyang: Yi Mile Shang Xia Jing weizhu de yanjiu’ 漢譯佛經中的彌勒信仰 ——彌勒上、下經為主的研究 [Research on Maitreyanism in Han Translations of Buddhist Texts-Focused Around Rising and Rebirth Maitreyanism]. Wenshizhe Xuebao 文史哲學報 [Humanities Report] 35 (December, 1987): 119-81.

Yang Weizhong 楊維中. ‘Dongjin shiqi Jingzhou Fosi kao’東晉時期 荊州佛寺考 [Research of Monasteries in Jingzhou During the Eastern Jin Period]. Baobua Temple. Accessed February 28, 2017. http://www.baohuasi.org/gnews/2010318/2010318199612.html. Zhang Gong 張弓. Han Tang Fosi wenhua shi 漢唐佛寺文化史 [Cultural History of Buddhist Temples During the Han and Tang Dynasties]. Beijing: Zhongguo shehui kexue chubanshe 中 國社會科學出版社, 1997. 
Zhang Weiran 張偉然. Hubei lishi wenhua dili yanjiu 湖北歷史文 化地理研究 [Research on History, Culture, and Geography of Hubei]. Wuhan: Hubei jiaoyu chubanshe 湖北教育出版社, 2000. Zhang Wenliang 張文良. 'Mile xinyang shupin'彌勒信仰述評 [Discussion of Maitreyanism]. Master's thesis, Department of Philosophy, Renmin University 人民大學, 1990. Collected in Zhonguo Fojiao xueshu lundian 中國佛教學術論典 [Discussion on China Buddhism Learning]. Kaohsiung: Foguang Shan Wenhua Shiye Gongsi 佛光山文化事業公司, 2001.

Zhang Xun 章巽, annot. Faxian zhuan jiaozhu 法顯傳校注 [Account by Faxian, collated and annotated]. Beijing: Zhonghua Shuju 中 華書局, 2008.

Zhang Zikai 張子開 (Zhang Yong 張勇). 'Nianfo jingtu guannian yu zaoqi Chanzong Mile xinyang’ 念佛、淨土觀念與早期禪宗彌勒 信仰 [Chanting of the Buddha's Names and Pure Land Notions as well as Early Chan Buddhism Maitreyanism]. Zongjiao xue yanjiu 宗教學研究 [Religious Studies Research] 4 (2006): 82-89. 